\section{Satisfaction Assessment of Housing Users in Tripoli - Libya}

Omar Ali Alameen ${ }^{1}$, ORCID: 0000-0003-1730-5276

Prof. Dr. Gülser Çelebi², ORCID: 0000-0001-5439-9764

Prof. Dr. Mehmet, Tunçer 3 , ORCID: 0000-0002-1591-6383
Keywords

sustainability, sustainable housing, Libya, Tripoli, ecology, climate change

\section{Abstract}

Most communities, especially professionals such as architects, infrastructural engineers and city planners, pay particular attention to sustainable housing, which is important for housing development as the first place in which people spend most of their time. In addition, residential buildings cover more than $50 \%$ of the total area of any city in Libya. For the city of Tripoli as a case study, the growth of the city has increased due to the growth of the Libyan economy as well as due to high oil prices during the 1970s. As a result, there has been an increase in natural population growth as well as migration from neighbouring cities. To accommodate population growth, governments have implemented a number of development projects, particularly in the housing sector. The aim of this paper is to evaluate the satisfaction of housing users in accordance with the previous housing policies of successive Libyan governments. The data was collected by means of questionnaires concerning the social aspects of housing occupants and their suitability for the Libyan family both currently and in the future. Moreover, there remains the question of what characteristics should be taken into account when implementing future housing projects. The study included cases of housing projects implemented for the purpose of assessing the satisfaction of users with projects to implement the principles of "Sustainable Housing." The survey included four residential projects carried out in the city of Tripoli for the research. The sites are: (i) Airport Road East Housing Project (ii) Al Hadba Khdra Housing Project (iii) Ghot AshAhaal Housing Project (iv) Souq-Atolata (North) Housing Project. The paper also aims to benefit from the study results for the implementation of the "Sustainable Housing Policy in Libya: A Case Study of Tripoli" for the purpose of applying the principles of social sustainability to housing, especially in Tripoli and Libya in general. Additionally, this paper will be useful for planning and architectural professionals.

\section{Article Information}

Received: 27.06.2019

Accepted: 22.01 .2020

Available Online: 28.01.2020

Article Info: This study was produced from the ongoing doctorate research of Omar Ali Alameen at the Department of Interior Architecture, Cankaya University.

1. Department of Interior Architecture, Cankaya University, Ankara, Turkey, omar3228570@gmail.com

\section{Department of Interior} Architecture, Cankaya University, Ankara, Turkey, gulsercelebi@cankaya.edu.tr

3. Department of City and Regional Planning, Cankaya University, Ankara, Turkey, mtuncer@cankaya.edu.tr 


\section{Libya'da Sürdürülebilir Konut Politikası: Tripoli Örnek Alan Çalışması}

Omar Ali Alameen¹, ORCID: 0000-0003-1730-5276

Prof. Dr. Gülser Çelebi², ORCID: 0000-0001-5439-9764

Prof. Dr. Mehmet, Tunçer ${ }^{3}$, ORCID: 0000-0002-1591-6383

\section{Anahtar Sözcükler}

sürdürülebilirlik, sürdürülebilir konut, Libya, Trablusgarp (Tripoli), ekoloji, iklim değişikliği

\section{$\ddot{\mathbf{O} z}$}

Bir çok toplumda; mimarlar, altyapı mühendisleri ve şehir plancıları gibi uzmanlar, insanların zamanlarının çoğunu geçirdiği mekan olarak konutun, gelişimi için önemli olan sürdürülebilir konutlara özel bir önem verirler. Libya'da da konut binaları Libya'daki herhangi bir kentin toplam alanının $\%$ 50'sinden fazlasını kapsamaktadır. Bu çalışmada alan incelemesi olarak Libya'nın Trablusgarp şehri ele alınmıştır. 1970'lerde yüksek petrol fiyatları nedeniyle şehrin büyümesi artmıştır. Sonuç olarak, komşu şehirlerden göçün yanı sıra doğal nüfus artışında da bir artış olmuştur. Nüfus artışına uyum sağlamak için, hükümetler özellikle konut sektöründe bir dizi kalkınma projesi gerçekleştirmiştir. Bu çalışmanın amacı da, farklı kalkınma projelerindeki konut politikaları bağlamında konut kullanıcılarının memnuniyetini değerlendirmektir. Veriler anketler yoluyla elde edilmiştir. Bu anketlerde konut sakinlerinin sosyal durumlarına göre konutların bugün ve gelecekte Libya ailesine uygunluğu sorgulanmıştır. Ayrıca, gelecekteki konut projelerini uygularken hangi özelliklerin dikkate alınması gerektiği sorusu da anketlerde sorulmuştur. Çalışmada, "Sürdürülebilir Konut" ilkelerini uygulamak üzere oluşturulmuş konut projeleri üzerinden kullanıcıların memnuniyetini değerlendirmek amacıyla da sorgulama yapılmaktadır. Örnekler, Trablusgarp'ta dört farklı alandaki konut projelerini içermektedir. Bu alanlar: (i) Havaalanı Yolu Doğu Konut Projesi (ii) Al Hadba Khdra Konut Projesi (iii) Ghot Ash-Ahaal Konut Projesi (iv) Souq-Atolata (Kuzey) Konut Projesi. Çalışma aynı zamanda, Trablusgarp ve Libya'da, sosyal sürdürülebilirlik prensiplerini konutta uygulamak amaciyla "Libya'da Sürdürülebilir Konut Politikası: Tripoli Örnek Alan Çalışması”"nın sonuçlarından da yararlanmayı amaçlamaktadır. Ayrıca, bu makalenin planlama ve mimarlık profesyonelleri için de faydalı olacağ1 düşünülmektedir.

\section{Makale Bilgileri}

\author{
Alınd1: 27.06.2019 \\ Kabul edildi: 22.01 .2020 \\ Erişilebilir: 28.01.2020
}

Makale Bilgisi: Bu çalışma, Omar Ali Alameen'in, Çankaya Üniversitesi, İç Mimarlık Bölümünde hazırlamakta olduğu doktora araştırmasından üretilmiştir.

1. İç Mimarlık Bölümü,

Çankaya Üniversitesi, Ankara,

Türkiye,omar3228570@gmail.com

2. İç Mimarlık Bölümü,

Çankaya Üniversitesi, Ankara,

Türkiye,

gulsercelebi@cankaya.edu.tr

3. Şehir ve Bölge Planlama Bölümü, Çankaya Üniversitesi, Ankara, Türkiye,mtuncer@cankaya.edu.tr 


\section{INTRODUCTION}

Modern housing is no longer a refuge from nature, climate and natural hazards. In fact, housing and buildings reflect many cultural and social requirements, such as the daily living conditions of family members. Housing is also provided to people to have places to relax, receive guests, care for children, sleep, study, and cook, eat, do ablutions for personal hygiene and in some cases it may include workplaces. Housing is characterized by many elements with its social and economic characteristics. It has a symbolic meaning and it has a strong impact on the quality of life. Access for families to adequate housing, which provides them with functional needs, social status and psychological comfort within their financial capabilities, is a major requirement in contemporary urban societies (Henilane, I., 2016). In addition, housing is one of the pillars that contribute to the development of the family, which is a basic requirement, and priority in the list of hopes and aspirations to obtain adequate housing for any family, and the ability to own one is a prerequisite. In addition to providing daily shelter for the family, housing positively affects psychological, social and economic stability. It is also considered to be the most important and most valuable attribute in their life. Access to adequate housing that meets the needs of the family often consumes a large part of their income. However, it is an important development goal in all countries of the world.

This paper on satisfaction assessment of housing users includes four implemented housing projects in the city of Tripoli as a case study of this research. The objective of the study is to evaluate the housing in the aforementioned projects as a satisfaction assessment of housing users to determine the extent of the possibility of benefiting from the application of the principles of sustainability through the social and cultural side in the field of housing for the case study in particular and for Libya in general.

\section{LITERATURE REVIEW}

\section{Sustainable Housing}

Sustainable housing is defined as housing that meets the needs of today's people without compromising the ability of future generations to meet their needs (Paul G. Tuohy, 2006). Roaf et al. (2005) defined the eco-house as a house that is closely connected to the site, society, climate, region and planet. Therefore, housing is sustainable if "everyone has the opportunity of access to a home that is decent; if it promotes social cohesion, well-being and self-dependence" (Edwards, 
2000). Moreover, UN-Habitat, 2012 defined sustainable houses which were designed, built and managed according to the items below:

- $\quad$ Healthy, durable, safe and secure;

- Affordable for the whole spectrum of incomes;

- Using ecological, low-energy and affordable building materials and technology;

- $\quad$ Resilient in resisting potential natural disasters and climatic impacts;

- Connected to decent, safe and affordable energy, water, sanitation and recycling facilities;

- Using energy and water most efficiently and equipped with certain on-site renewable energy generation and water recycling capabilities;

- $\quad$ Not polluting the environment as well as being protected from external pollution;

- Well connected to jobs, shops, health- and child-care, education and other services;

- Properly integrated into and enhancing the social, cultural and economic fabric of the local neighbourhood and wider urban areas;

- $\quad$ Properly run and maintained, timely renovated and retrofitted (UN Habitat, 2012).

Aisha A. Almansuri et al. (2010) defined sustainable housing thus: "Sustainable housing is a form of affordable housing that also incorporates environmentally friendly and community-based practices, to reduce the negative impact that homes can have on the environment through choosing better building materials and environmental designs."

\section{House and Home}

Housing can generally be characterized as a physical unit, a defined space for residents, providing shelter and protection for domestic activities and concealment, and an entity-separating private from public domains (Lawrence, 1987 and Rapoport, 1995). Additionally, a house is a home when it shelters the body and comforts the soul (Paul Hendler and Lisa Thompson-Smeddle, 2000). Also, a house is a home; it is also the main building block of successful communities (Edwards B. and David Turrent, 2005).

\section{Housing Policies in Libya}

A housing policy is a statement of what is (or is going) to be done to provide housing (Mumtaz, 1995). As in most developing countries, housing is an important issue in the social and economic development plans in Libya. Therefore, it has been a high priority for the Libyan government since the country attained its political independence in 1951 . As a result, more than $77 \%$ of the physical built environment in Libya was residential buildings (NCID, 1995), and a series of strategies have been adopted in order to deal with housing issues. These concerns public housing programs, slum 
clearance, the establishment of new towns and cities, housing loan schemes, and public housing investment (World Bank, 1960; et al, 1990).

According to Omar (2003) and Mukhtar, (1997), the main inadequacies in developing and implementing a housing policy and program for Libya is as follows:

- Lack of responsiveness to housing needs in terms of social life, cultural and environmental factors. Because of this, most public housing has used foreign concepts in planning and designing projects.

- Deficiency of local specialists, technical personnel and building materials to complete the objectives of the housing sector. The result is a dependence on importing them from abroad. Consequently, the design of most houses is highly dependent on foreign skill and labour as well as on imported materials.

- The absence of private rented housing has caused some deficits in the housing supply;

- Public housing projects have not always included the necessary services. In some projects, the basic infrastructure and services, such as the schools, roads and other civil services, were not constructed at the same time. The housing policy in Libya mostly concentrates on quantity, not quality, and they are unsuitable for occupants and the environment.

\section{METHODOLOGY}

The research methodology used for this paper was the gathering of information from documentary sources and field surveys according to the following:

- Four sites were selected from housing projects implemented in Tripoli as the case in the research.

- Survey interviews would gather information and data through personal interviews and through a questionnaire with a sample of users.

- The research methodology focuses on analytical research and analysis implemented questionnaire using SPSS (version 25).

The study of environmental impacts on the design of layout plans and architectural elements in residential settlements of the case study sites was performed using SWOT analyses. Figure 1 illustrates the research process including the methodology studies and analyses of systematic research information. 


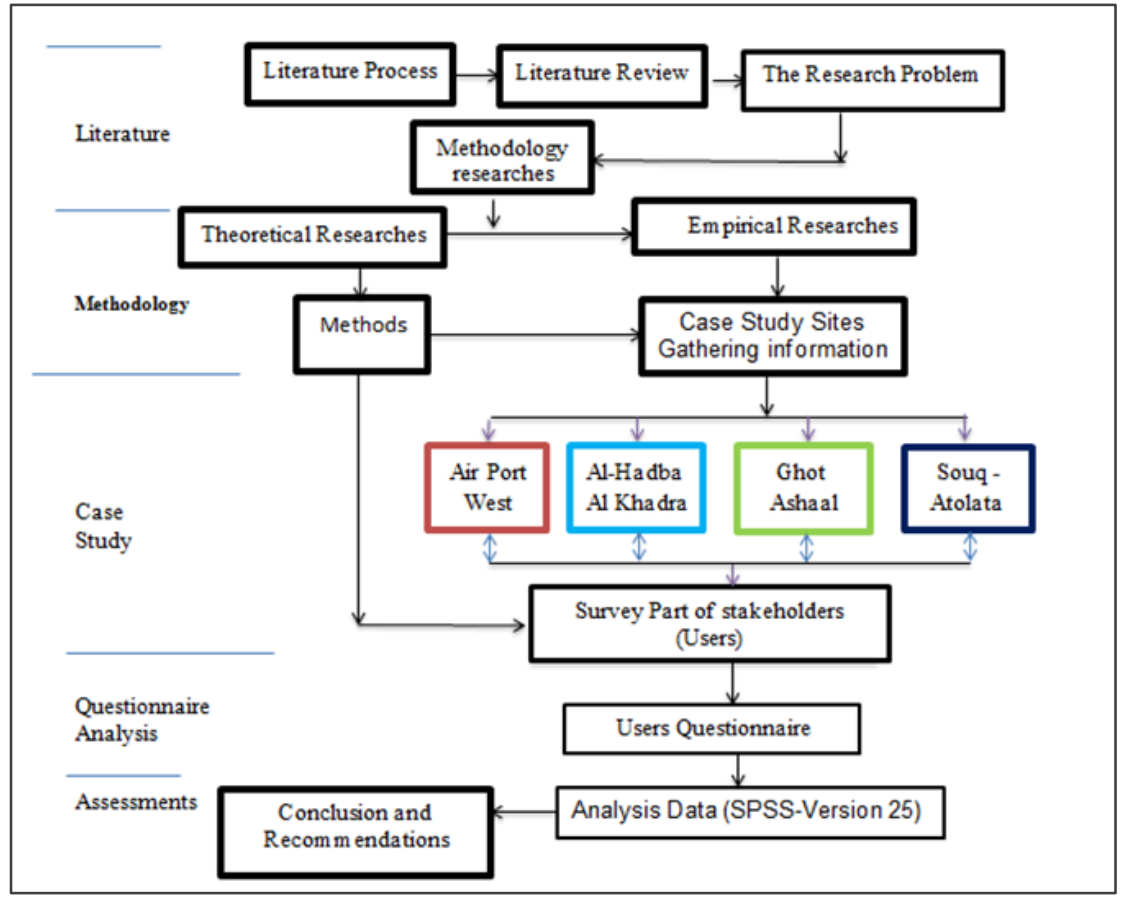

Figure 1. Methodology

\section{Case Study - The City of Tripoli in Libya}

Tripoli city originated during the settlement of the Phoenicians (in the 7th century BC) on the west coast of Libya with the establishment of the three major commercial centres of Oia (Tripoli), Subrata and Leptis Magna around 800 B.C. Some historians believe that the Phoenicians came from the eastern coast of the Mediterranean Sea. Another historian claimed that Oia (Tripoli) was founded by Sicilians who would have been Phoenicians already abroad, not native Sicilians (Kshedan, 1984). Later, the eastern province of the Carthaginian state was formed and accounted for the late Roman name Tripolitania "Three Cities". Figure 2 illustrates the Phoenician colonies on the Libyan coast.

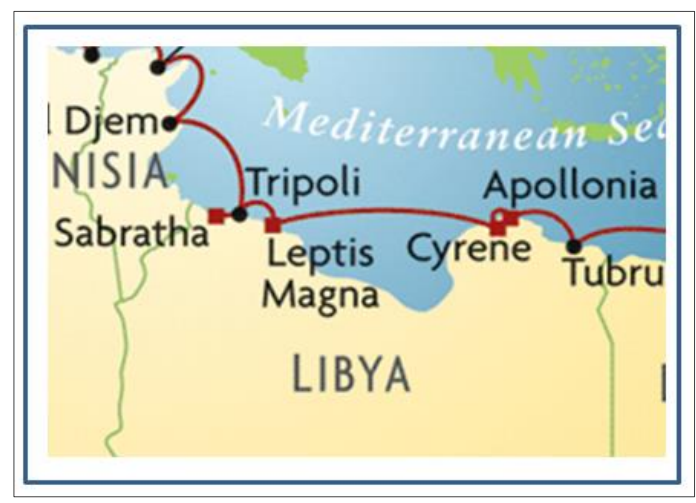

Figure 2. Phoenician colonies on the Libyan coast (Source: Betchart Expeditions, Africa, betchartexpeditions.com, 11 Dec 2018) 
The strategic location of Tripoli, which links Africa with other continents, especially Europe, has made it a harbinger of the colonial powers that swept the city through its various phases of development in terms of the architectural identity of its buildings and the organization of its streets. The development of the city can be summarised historically as:

1. Pre-Colonial Stage (7th Century BC to AD 1911)

2. The Colonial Phase (1911 to 1951)

3. The Post Colonial Stage (1951-)

Figure 3 shows a map of the latest proposal for the urban regeneration of Tripoli (2009) and Figure 4 shows the region around Tripoli.

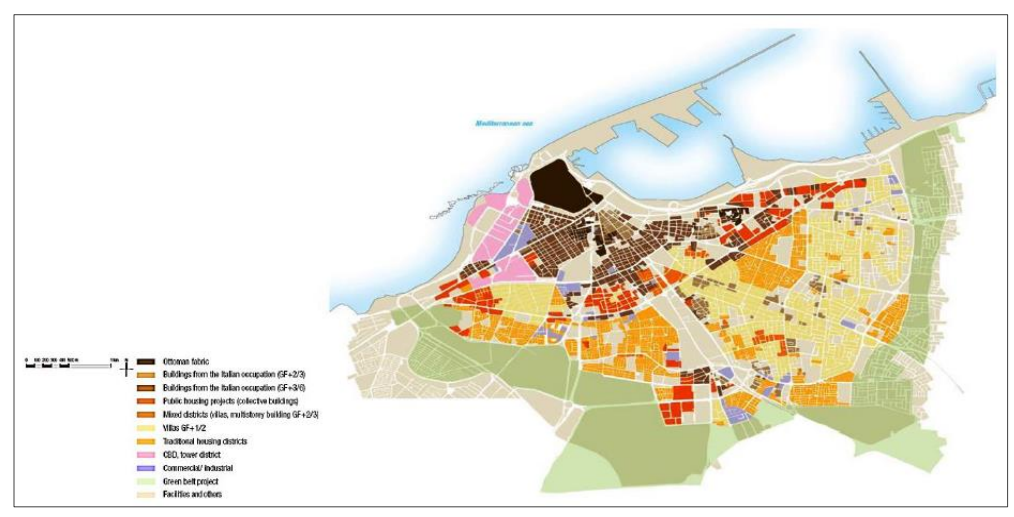

Figure 3. Map of the latest proposal for Tripoli's urban regeneration (2009) Tripoli's urban regeneration proposal aims to solve the urban problems caused by delaying the implementation of past generations of master plans for the city since 1968.

(Source: Tripoli Urban \& Architectural Charter, ECOU/AKT-IAURIF Report, 2009)

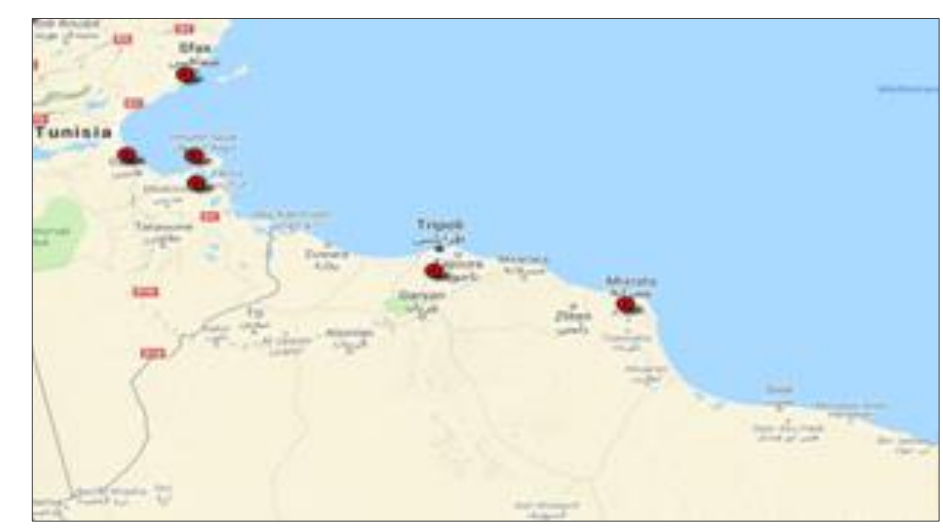

Figure 4. Tripoli region (Source: http://www.libya.climatemps.com, Jun, 2018) 


\section{Field Survey of Selected Housing Sites}

Information was collected in Tripoli from 17 March 2018 to 3 April 2018 and included the following governmental institutions:

- Project Management at the Ministry of Housing;

- Authority of Urban Planning;

- Savings and Real Estate Investment Bank;

- Management of social security fund projects;

- Organization for the Development of Administration Centers (ODAC);

- The former General Authority for Housing (project implementation of 2870 housing units in Tripoli), currently belonging to the Housing and Infrastructure Board; and

- The management of social solidarity fund projects.

Table 1. Summary of site data collection

(The information was collected for six occupied housing project sites as summarized in

Table 1 and Figure 5)

\begin{tabular}{|c|c|c|c|c|}
\hline No & Project Name & $\begin{array}{l}\text { Dwelling } \\
\text { Numbers }\end{array}$ & $\begin{array}{l}\text { Population } \\
\text { Numbers }\end{array}$ & Remarks \\
\hline 1 & Souq- Atolata (North) & 240 & 1,224 & $\begin{array}{l}6 \text { multi-storey buildings consisting } 12 \\
\text { floors }\end{array}$ \\
\hline 2 & Souq- Atolata (south) & 308 & 1,632 & 8 multi-storey buildings consisting 12 floors \\
\hline 3 & Ghot Ash-Ahaal & 100 & 510 & $\begin{array}{l}14 \text { multi-story buildings consisting } 4 \text { floors, } \\
\text { including ground floor as shops }\end{array}$ \\
\hline 4 & Al-Hadba Khdra & 1,088 & 5,550 & $\begin{array}{l}49 \text { multi-story buildings consisting } 10 \\
\text { floors }\end{array}$ \\
\hline 5 & Airport-East & 224 & 1,254 & $\begin{array}{l}16 \text { multi-story buildings consist of } 7 \text { or } 8 \\
\text { floors including ground floor as shops }\end{array}$ \\
\hline 6 & Air Port-West & 592 & 3,019 & $\begin{array}{l}28 \text { multi-storey buildings consist of } 7 \text { or } 8 \\
\text { floors including ground floor as shops }\end{array}$ \\
\hline
\end{tabular}




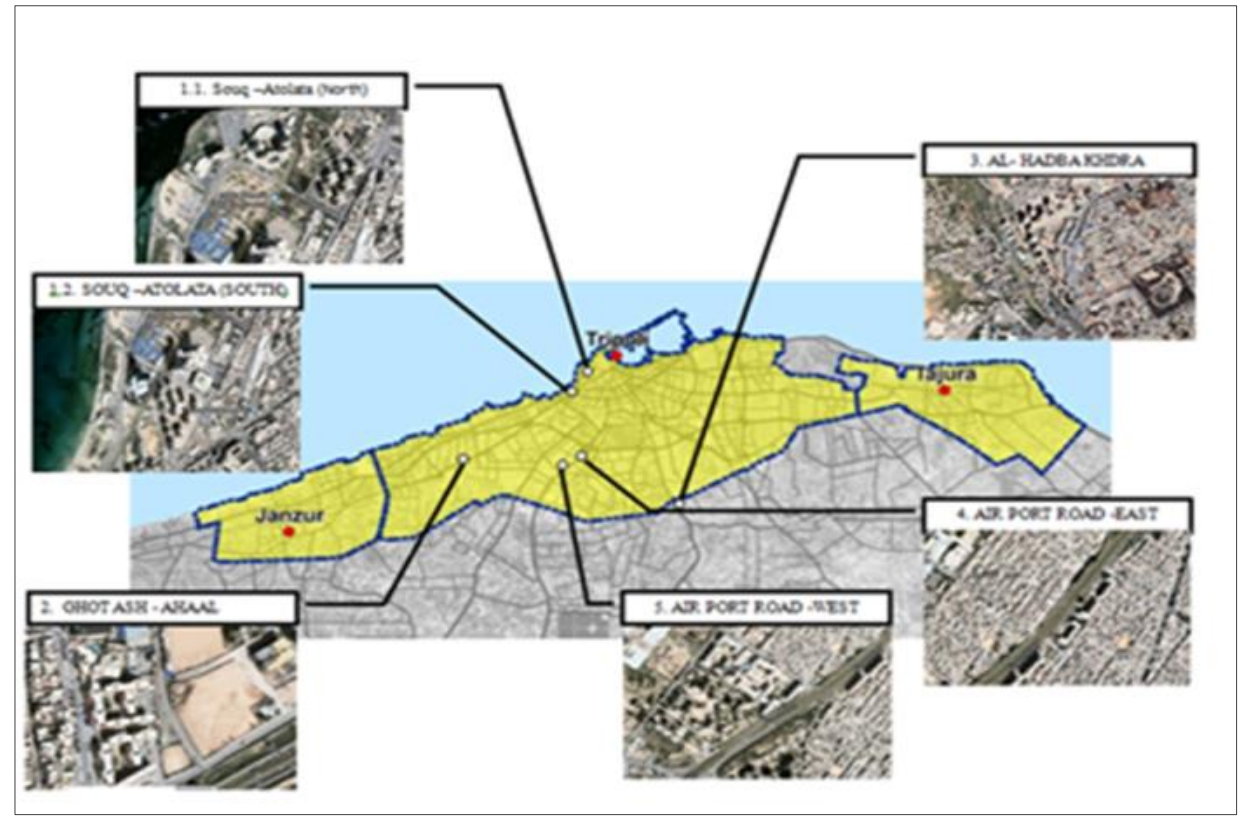

Figure 5. Case Study Field Survey Sites

\section{Criteria for Selecting Study Sites}

Through the fieldwork survey, information was collected for the following sites:

1. Souq Atolata (South);

2. Souq Atolata (North);

3. Ghot Ash Ahaal;

4. $\quad \mathrm{Al} \mathrm{Hadba} \mathrm{Khdra;}$

5. AirPort East; and

6. Air Port West

Through documentary sources and field surveys, the information was collected about housing projects implemented in Tripoli Libya which occupied by the population. The sites in the case study were selected according to the following reasons and criteria:

1. Availability of information about the selected sites;

2. completion of construction and inhabitation process ;

3. We selected different parts of Tripoli city as sampling the different housing;

- Residential and population density;

- Number of housing units; 
- Technical status; and

- Characteristics of the project site in Tripoli.

And by applying the criteria specified above, the sites are shown in the following, Table 2 show the main information about the sites selected.

Table 2. Selected Study Sites

\begin{tabular}{c|l|c|c|}
\hline NO & \multicolumn{1}{|c|}{ Site Project } & $\begin{array}{c}\text { Number of } \\
\text { housing unites }\end{array}$ & $\begin{array}{c}\text { Number of } \\
\text { inhabitants }\end{array}$ \\
\hline 1 & Air Port-East & 592 & 3315 \\
\hline 2 & AL- Hadba Khdra & 1088 & 6093 \\
\hline 3 & Ghot Ash - Ahaal & 100 & 560 \\
\hline 4 & Souq - Atolata ( North) & 224 & 1344 \\
\hline
\end{tabular}

\section{Selected Sites Information}

During survey work and related documents collection, the following information was obtained.

\section{Air Port East Housing Project}

The site consists of 224 housing units distributed among 16 multi-story buildings, some of which consisting of 8 floors, including the ground floor as shops and others part of the buildings consisting of 7 floors. The project was implemented in 1997 over an area of 14,995 m2. The number of inhabitants is estimated as $=1,254$ residents in total with respect to the average household size as $5.6(224 \times 5.6)$. (See Figures 6 and 7$)$.

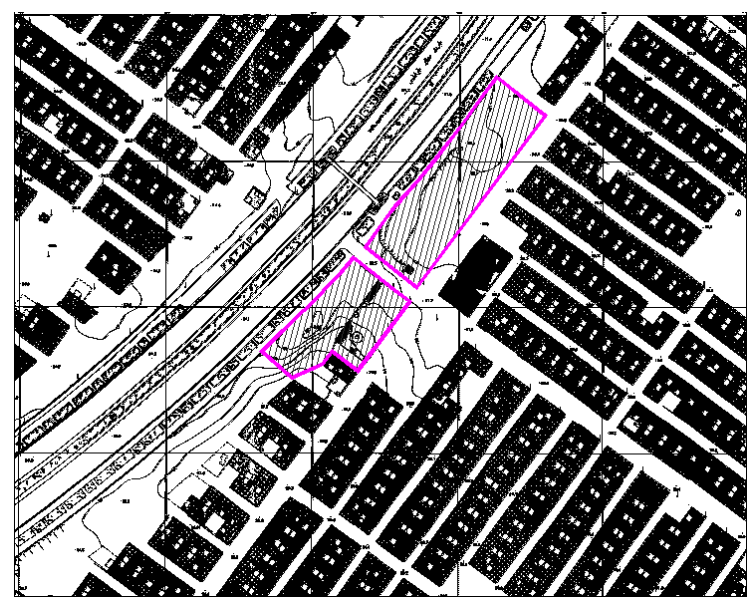

Figure 6. Site Location Plan AirPort Housing Project (Source: Housing \& Infrastructure Board, CMHP 2870 - 2018) 

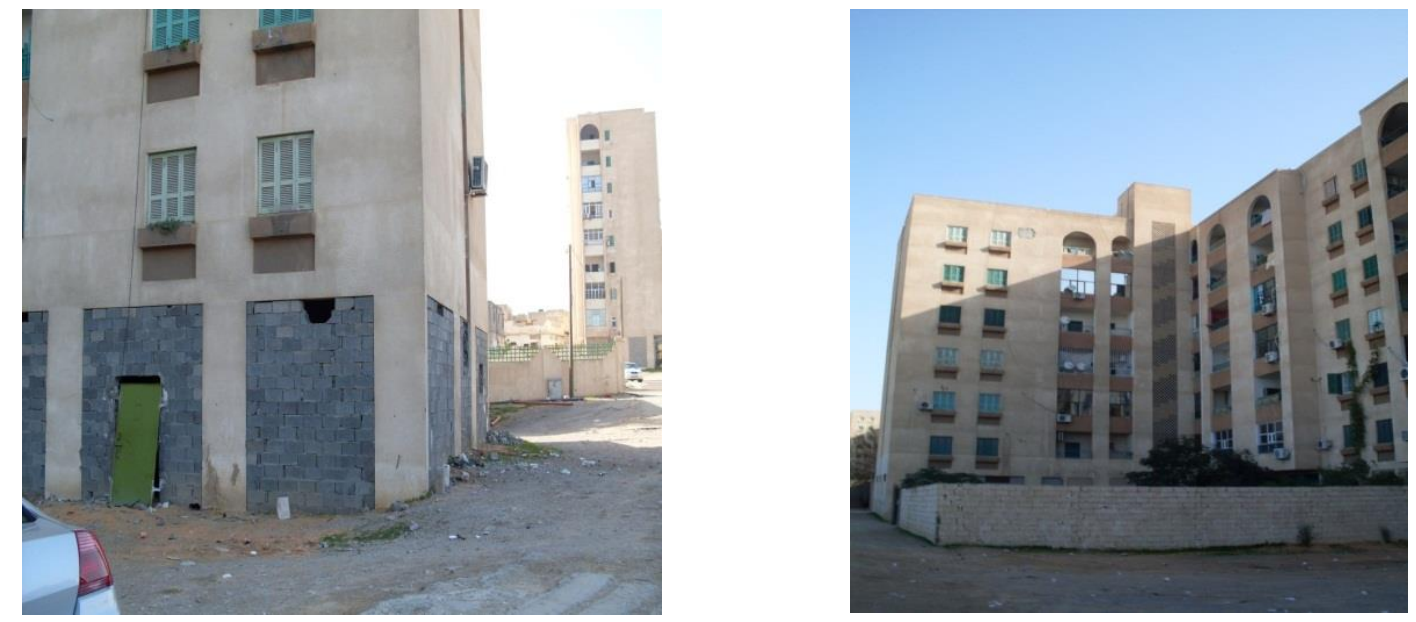

Figure 7. A number of changes on the ground floor (left) and neglect of the site environment of residential buildings by users (right) (Source: O. A. Alameen archive)

\section{Al Hadba Khdra Housing Project}

The project is located in the Al Hadba Khdra area in the southern part of Tripoli near Salah ElDin Hospital. The project was implemented in 2008 by the Arab Union Contracting Company on an area of $175,257 \mathrm{~m} 2$. The project consists of 49 residential buildings distributed on the site (see Figures 8 and 9) with 1,088 housing units distributed on 49 multi-story buildings, each building consisting of 9 or 10 floors, including a ground floor as shops in some buildings, the total number of inhabitants as 6098 residents $(1088 * 5,6)$.

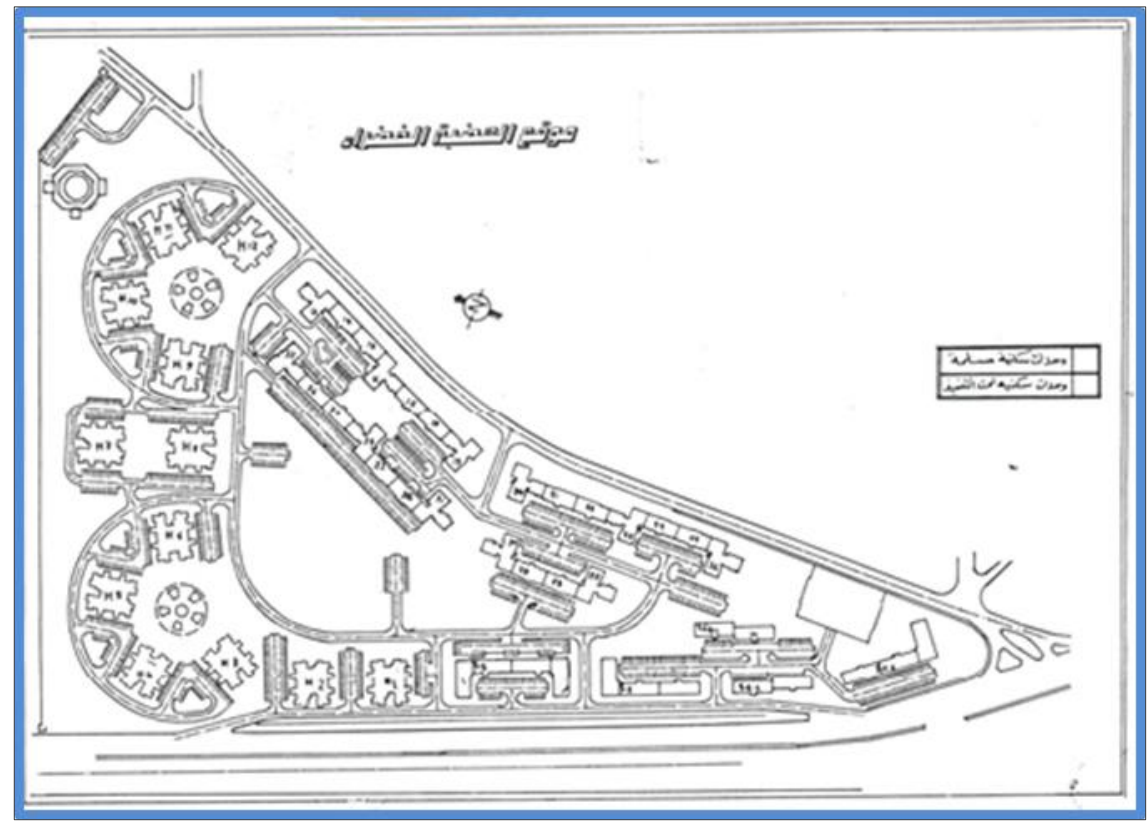

Figure 8. Layout Site Plan Al Hadba Khdra Housing Project (Source: Housing \& Infrastructure Board, CMHP 2870 - 2018) 

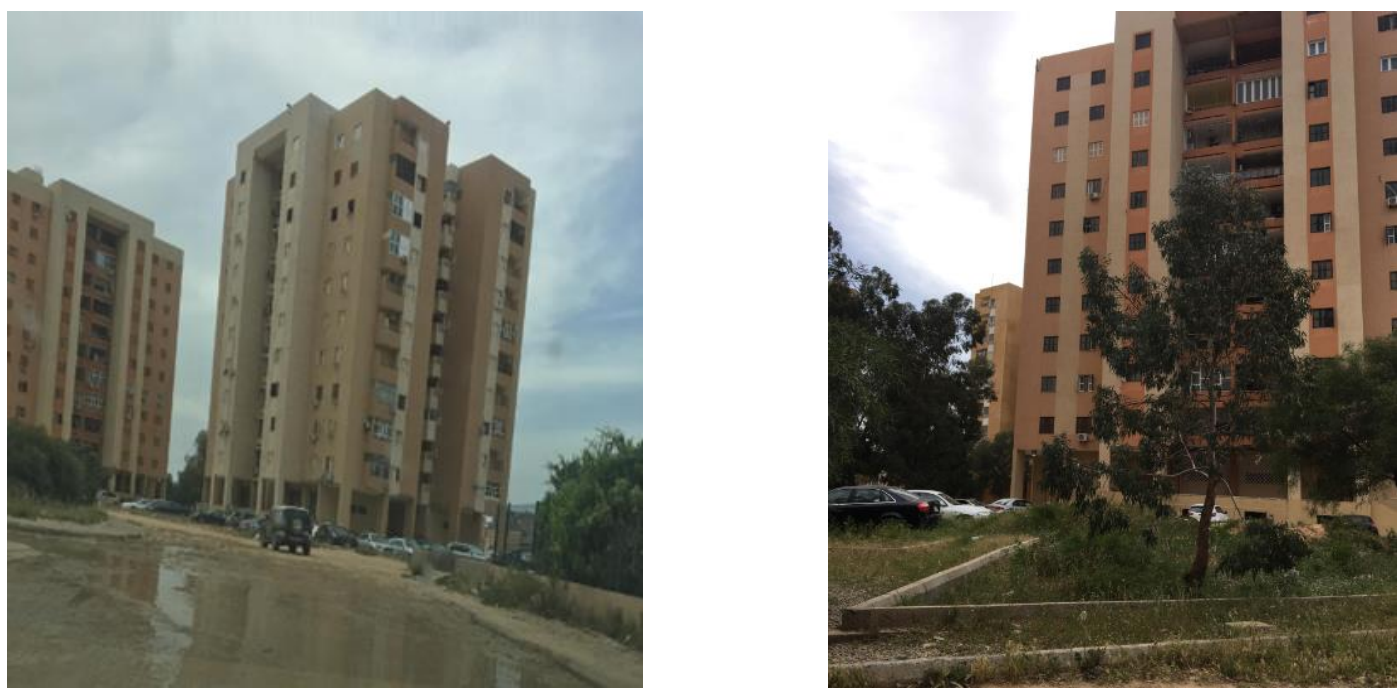

Figure 9. Incomplete environment (garden, pathways and access streets)

(Source: O. A. Alameen archive)

\section{Ghot Ash Ahaal Housing Project}

The project is located in the area of Ghot Ash Shaal in the south-western part of Tripoli near the tobacco factory south of the highway. The project was implemented in 2010 by the Chinese company, namely Ching Yan Construction and Engineering Co., Ltd. on an area of 14,077 m2. The project consists of 14 residential buildings distributed as follows (Figures 10 and 11):

- 8 buildings (ground floor +3 floors) consisting of 64 housing units

- 2 buildings (ground floor shops +3 floors) consisting of 12 housing units

- 4 buildings (ground floor + ground floor shops +3 floors) consisting of 24 housing units.

The site consists of 100 housing units distributed among 14 multi-story buildings, each building consisting of 4 floors including a ground floor of shops in some buildings. The number of inhabitants $=100 \times 5.6=560$ residents. 


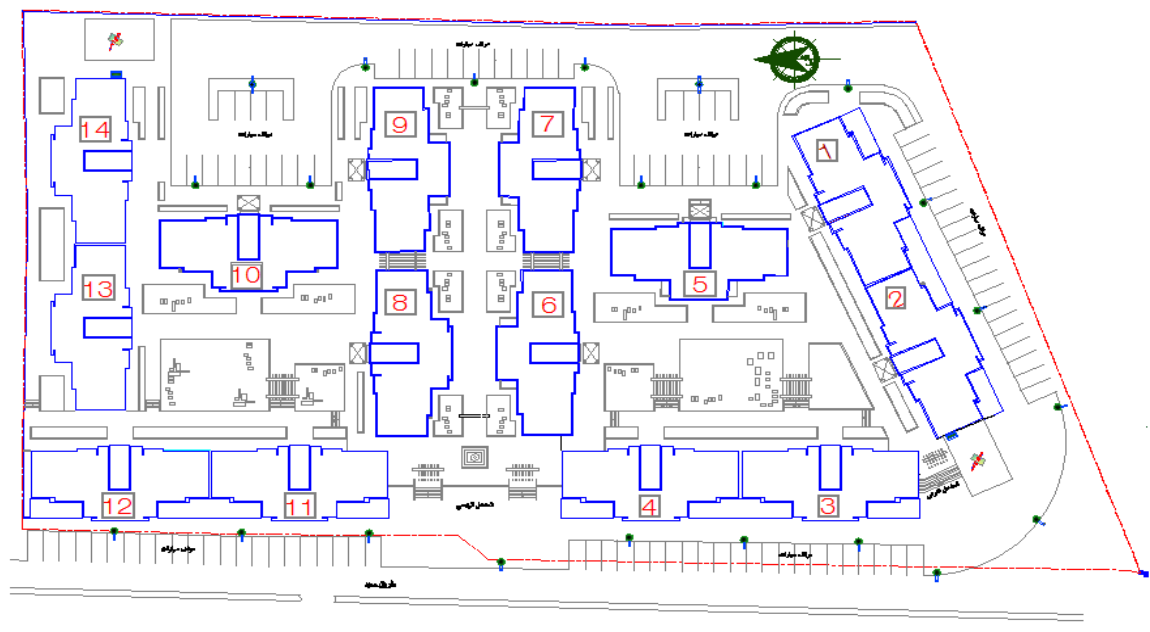

Figure 10. Layout plan, Ghot Ash Ahaal Housing Project (Source: Housing \& Infrastructure Board, CMHP 2870, 2018)
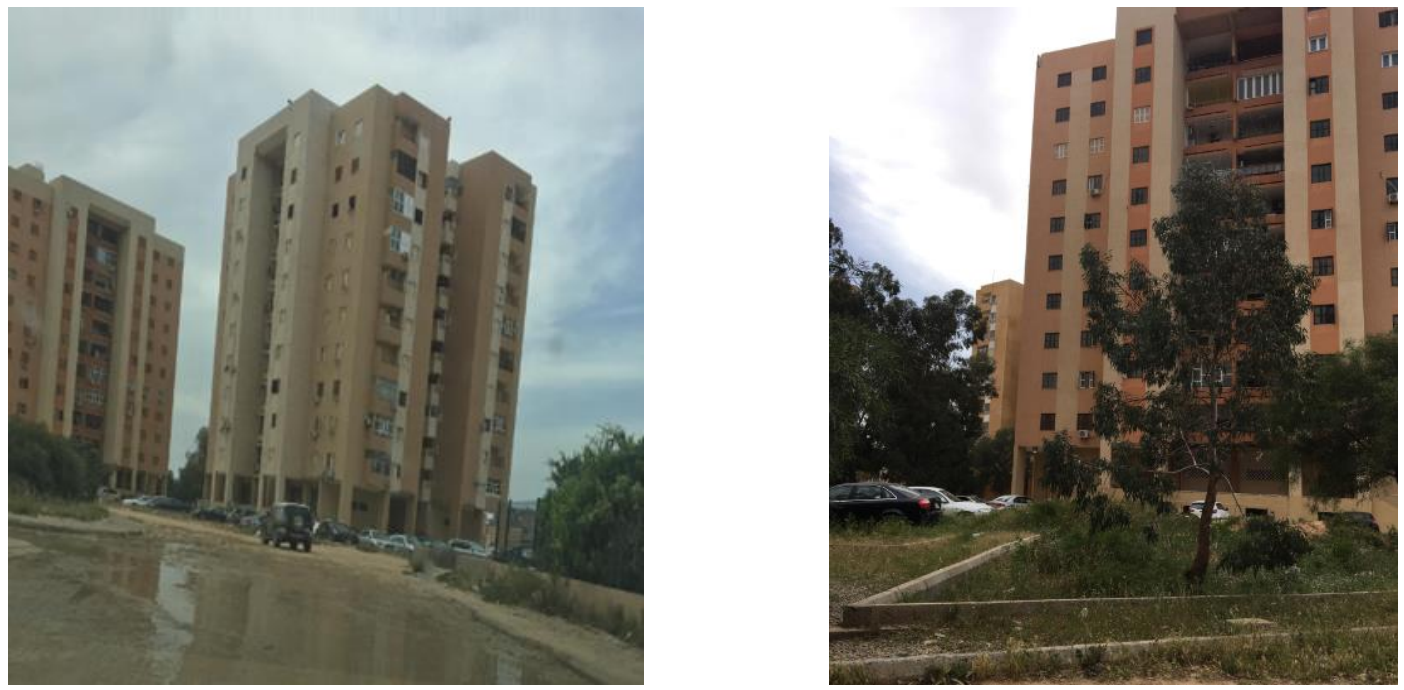

Figure 11. Photographs of the project (Source: O. A. Alameen archive)

\section{Souq Atolata (North)}

The project is located in the center (CPD) of Tripoli near the important hotels. The project was implemented in 2008 by the Arab Union Contracting Company on an area of 26,159 $\mathrm{m} 2$. The project consists of 6 residential buildings, distributed as in Figures 12 and 13 includes 240 housing units, distributed over 6 multi-story buildings, each building consisting13 floors. The total number of inhabitants is 1,344 residents $(240 * 5,6)$. 


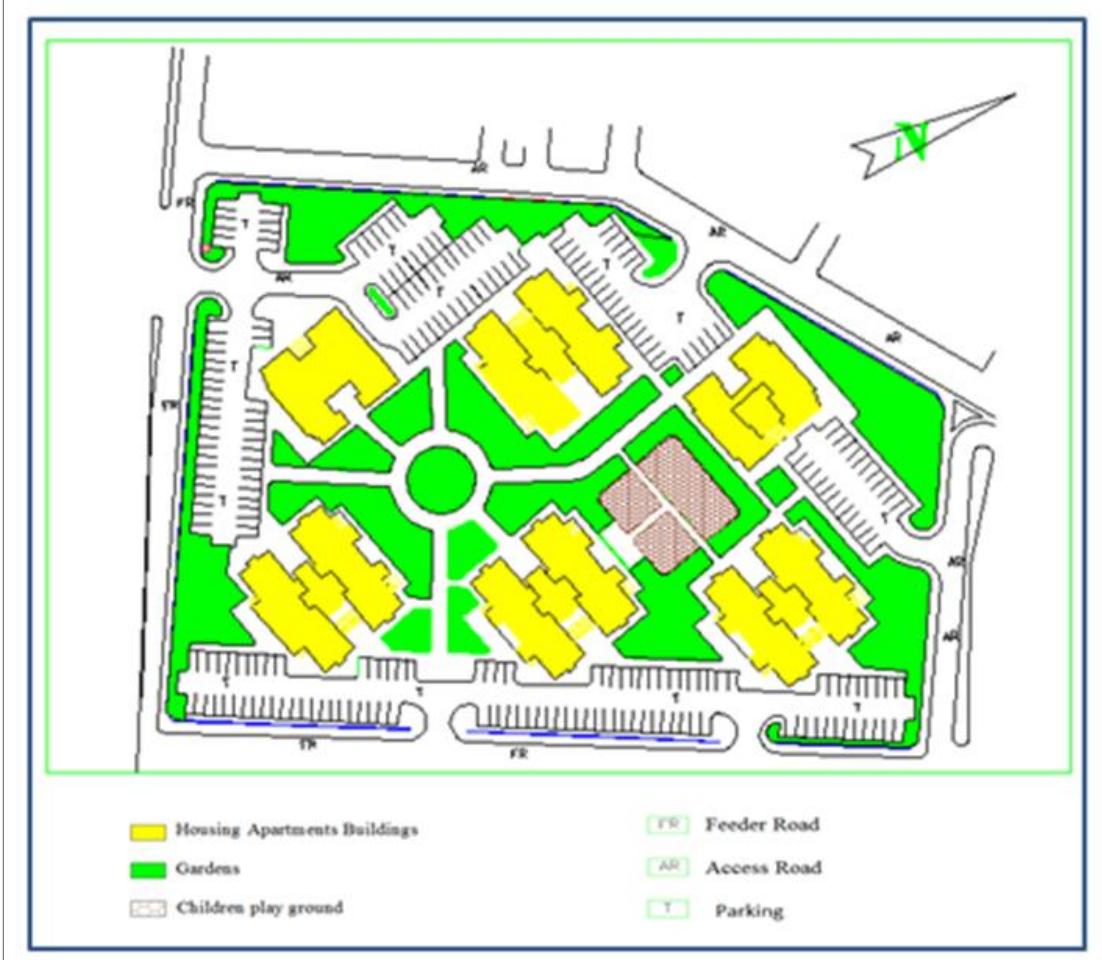

Figure 12. Layout plan of the Souq Atolata (North) Housing Project (Source: ODAC, 2018) \& redrawing by Alameen A. O., 2019)
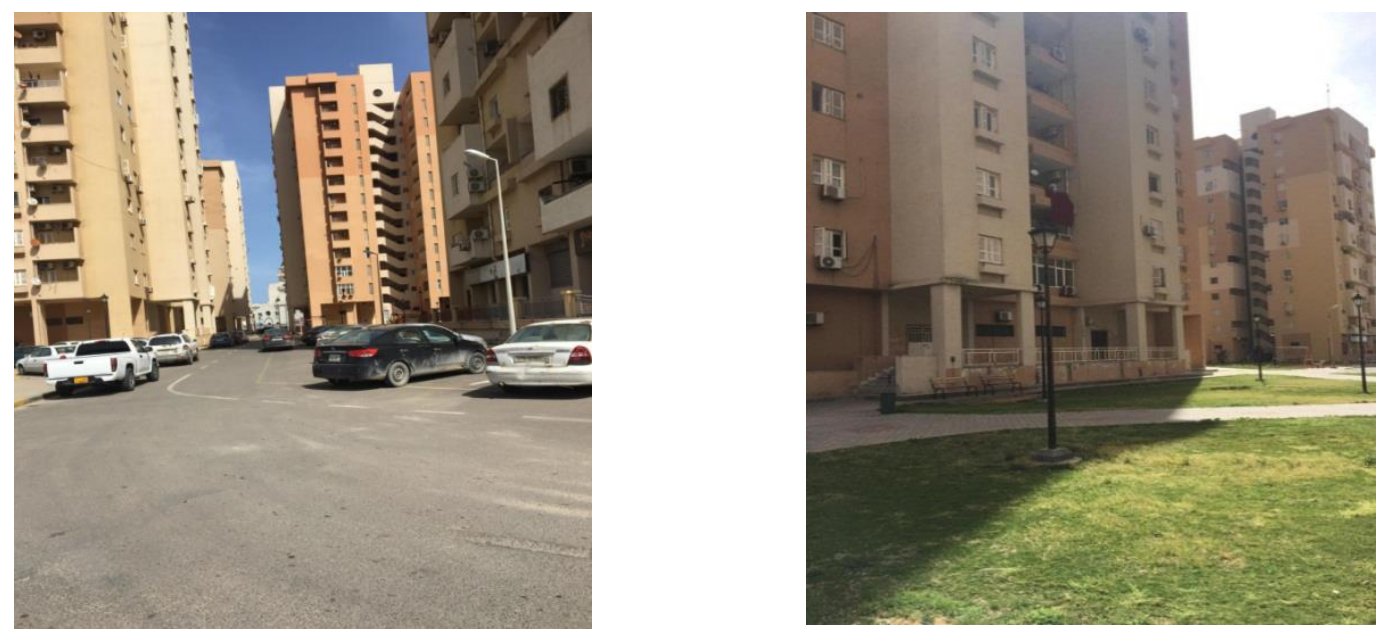

Figure 13. Site Environment (a good environment with garden and access streets) (Source: O. A. Alameen archive) 


\section{Data discussion and analysis}

The analysis of the information gathered from the user questionnaires was analyzed. An evaluation of the statistical data was made in accordance with the research methodology of this paper using SPSS (Statistical Package for the Social Sciences) which is considered to be the most important statistics program for this kind of research and it has more analysis details to produce good results.

\section{Selecting the sample and distribution of the questionnaires}

The sample of the user questionnaires was randomly selected and distributed among the four selected sites. A distribution team was formed to distribute the target number of 240 questionnaires starting on 10 October 2018. Unfortunately, after the distribution of the questionnaires were completed, the team was unable to gather them back due to the outbreak of violence in the southern part of Tripoli. This problem impacted the total number of questionnaires received. Table (3) explains the number of user questionnaires that were distributed to the housing sites during the field survey and the number of received questionnaires in addition to the rate of questionnaires being distributed and received.

Table 3. Questionnaires Distributed and Received

\begin{tabular}{|c|c|c|c|c|c|c|}
\hline NO & $\begin{array}{c}\text { Housing } \\
\text { Site Name }\end{array}$ & $\begin{array}{c}\text { Number of } \\
\text { Questionnair } \\
\text { es } \\
\text { Distributed }\end{array}$ & $\begin{array}{c}\text { Questionnai } \\
\text { res } \\
\text { excluded }\end{array}$ & $\begin{array}{c}\text { Percent of } \\
\text { Questionnaire } \\
\text { s Excluded }\end{array}$ & $\begin{array}{c}\text { Number } \\
\text { of } \\
\text { Questionn } \\
\text { aires } \\
\text { Received }\end{array}$ & $\begin{array}{c}\text { Percent of } \\
\text { Questionnaires } \\
\text { Received / } \\
\text { Distributed }\end{array}$ \\
\hline 1 & $\begin{array}{c}\text { AL- Hadba } \\
\text { Khdra }\end{array}$ & 100 & 10 & $10 \%$ & 58 & $58 \%$ \\
\hline 2 & Air Port-East & 60 & 8 & $13 \%$ & 18 & $\mathbf{3 0} \%$ \\
\hline 3 & $\begin{array}{c}\text { Ghot } \\
\text { Ash-Ahaal }\end{array}$ & 40 & 2 & $5 \%$ & 38 & $\mathbf{9 5 \%}$ \\
\hline 4 & $\begin{array}{c}\text { Souq- } \\
\text { Atolata } \\
\text { (North) }\end{array}$ & 40 & 6 & $15 \%$ & 18 & $\mathbf{4 0} \%$ \\
\hline & Total & 240 & 26 & $11 \%$ & 132 & $55 \%$ \\
\hline
\end{tabular}

\section{The validity of the Level of Satisfaction of Public Services}

A principal components factor analysis was conducted on 11 items. The Kaiser-Meyer-Olkin measure verified the sampling adequacy for the analysis; $\mathrm{KMO}=0.687$. A combination of two factors explains $42.125 \%$ of the variance. Item 1.11 (Availability and using common spaces: staircases, elevators) were excluded from the analysis due to low factor loading (0.344). Table 4 shows the factor loadings after rotation. After these results, it can be stated that the scale developed for measuring satisfaction in this study is valid. 
Table 3. Pattern Matrix a

\begin{tabular}{|c|c|c|}
\hline & \multicolumn{2}{|c|}{ Component } \\
\hline & 1 & 2 \\
\hline 1.9 Availability of public transportation: & 0.762 & \\
\hline 1.7 Availability of public utilities: & 0.742 & \\
\hline 1.8 Availability of commercial services: & 0.698 & \\
\hline 1.10 Availability of parks and children's playgrounds: & 0.689 & \\
\hline 1.6 Availability of public services: & 0.506 & 0.336 \\
\hline 1.3 Reported social situation: & & 0.736 \\
\hline 1.2 Maintaining family traditions: & & 0.647 \\
\hline 1.5 Reported economic situation: & & 0.594 \\
\hline 1.4 Reported family size: & & 0.575 \\
\hline 1.1 Strengthening social relationships: & & 0.418 \\
\hline 1.11 Availability and using common spaces: (staircases, elevators) & & 0.344 \\
\hline Explained Variance $(\%)$ & 27.331 & 14.794 \\
\hline Total Explained Variance (\%) & \multicolumn{2}{|c|}{42.125} \\
\hline Kaiser-Meyer-Olkin Measure of Sampling Adequacy & \multicolumn{2}{|c|}{0.687} \\
\hline \multicolumn{3}{|c|}{ Bartlett's Test of Sphericity: $\chi^{2}(55)=281.432, \mathrm{p}<0.001$} \\
\hline \multicolumn{2}{|c|}{ Extraction Method: Principal Component Analysis. } & \\
\hline
\end{tabular}

Table 5 presents the reliability of the satisfaction scale showing the reliability analysis for the satisfaction scale. The scale had good reliability with Cronbach's $\alpha=0.720$. Subscales of service availability satisfaction and social satisfaction have Cronbach's $\alpha=0.739$ and 0.587 , respectively. Although social the satisfaction subscale has a reliability value under 0.7 , Inter-Item Correlations are equal to 0.230 . With short scales (e.g., scales with fewer than ten items), it is common to find Cronbach values that are quite low (e.g., 0.5). It is recommended in this case to report the mean inter-item correlation for the items (Pallant, 2013). According to Briggs and Cheek (1986), an optimal range for the inter-item correlation would be 0.2 to 0.4 . Results indicate that the scale and its sub-scales can be used in the measurement of the indicated variable.

Table 4. Reliability of Satisfaction Scale

\begin{tabular}{|l|c|c|c|}
\hline & \multicolumn{3}{|c|}{ Reliability Statistics } \\
\hline Scale and subscales & $\begin{array}{c}\text { Cronbach's } \\
\text { Alpha }\end{array}$ & $\begin{array}{c}\text { Cronbach's Alpha Based on } \\
\text { Standardized Items }\end{array}$ & N of Items \\
\hline Satisfaction scale & 0.720 & 0.716 & 10 \\
\hline Service availability satisfaction & 0.739 & 0.738 & 5 \\
\hline Social satisfaction & 0.587 & 0.599 & 5 \\
\hline
\end{tabular}


The scale was used for measuring the use of for social satisfaction and suitability were (highly satisfied, satisfied, not satisfied and highly dissatisfied), and the next Figure 14 illustrates the users' survey on the frequency and percentage rates of opinions of users' houses in terms of strengthening social relationships. It shows that 99 respondents $(75 \%)$ were not satisfied and highly dissatisfied, while the remaining respondents were satisfied and highly satisfied.

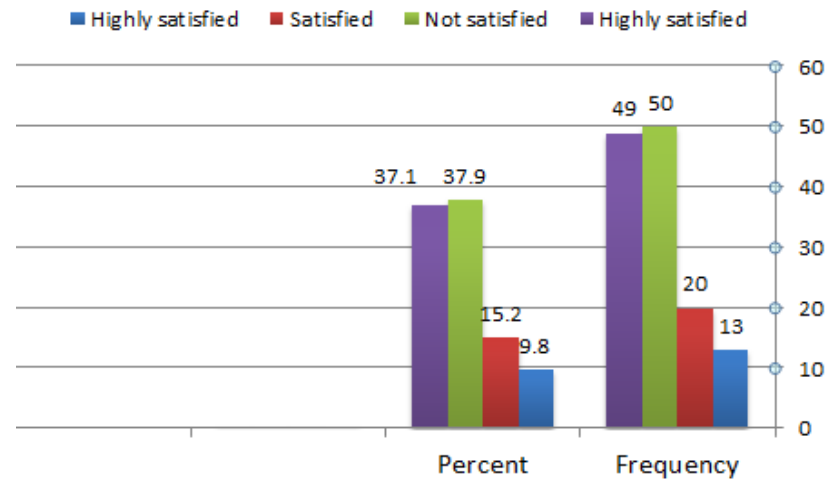

Figure 14. Frequency and percentage of user opinions for strengthening social relationships

The scale was used for measuring the use of social satisfaction and suitability were (highly satisfied, satisfied, not satisfied and highly dissatisfied), and the next Figure 15 presents the users' survey on the availability of services for the users. Most of the respondents were not satisfied $(40.2 \%)$ and highly dissatisfied $(13.6 \%)$. With regard to the availability of using common spaces (staircases, elevators, etc.), $39.4 \%$ of the respondents were satisfied, but $24.2 \%$ were highly dissatisfied. The availability of public transportation ranked third revealing that $31.8 \%$ of the respondents were highly dissatisfied and $27.3 \%$ were satisfied. The availability of public utilities ranked fourth with $35.6 \%$ of the respondents being dissatisfied and $18.9 \%$ being highly dissatisfied. Availability of commercial services ranked last showing that $7.6 \%$ of the respondents were highly dissatisfied and $33.3 \%$ were dissatisfied.

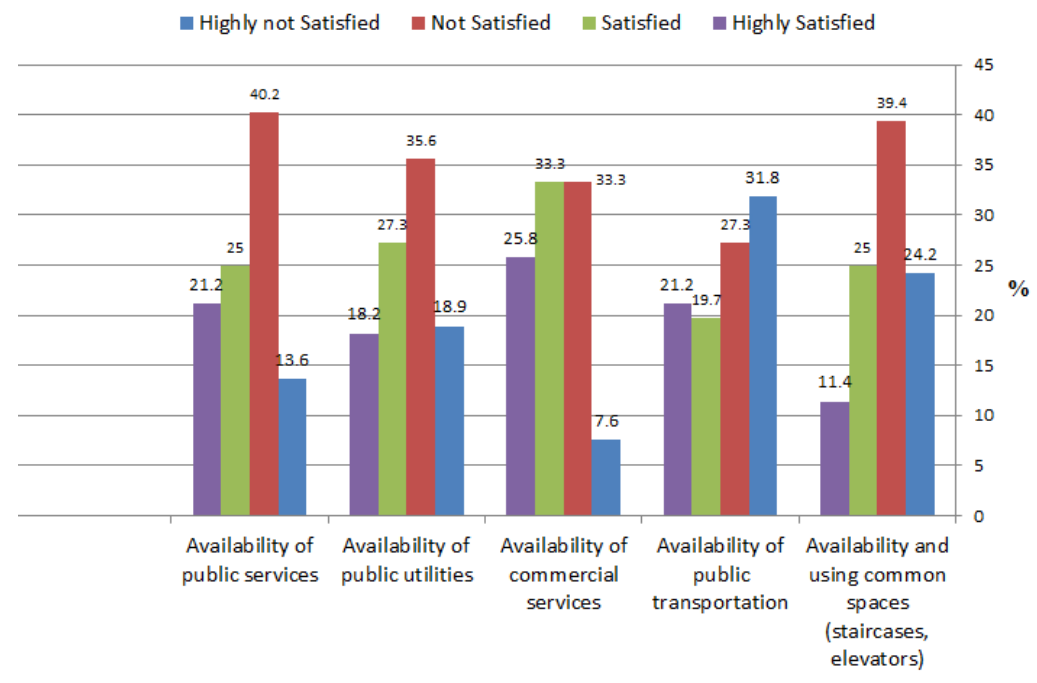

Figure 15. Availability of services for users 


\section{Descriptive statistics of Social satisfaction and suitability}

The scale was used for measuring the use of for social satisfaction and suitability were (highly suitable, suitable, unsuitable and highly unsuitable), and the Figures 16 and 17 show the frequencies and rates of the suitability of users' houses. It is shown that 72 of the respondents (ca. $54.5 \%$ ) found that their houses were unsuitable during religious and social events and 9 respondents (ca. $6.8 \%$ ) deemed their houses as being highly unsuitable. The factor ranking second was external noise within the houses, which had 63 respondents $(47.7 \%)$ indicating unsuitability and 22 (ca. 16.7\%) indicating high unsuitability. 56 respondents $(42.4 \%)$ found their residences unsuitable as favourite houses and 10 respondents $(7.6 \%)$ found them highly unsuitable. The privacy within the houses factor counted 67 respondents (50.8\%) deeming their homes suitable, but 33 (ca. 25\%) found this factor unsuitable. The factor of the suitability of neighbourhood relations had 65 people $(40.2 \%)$ respond as it being suitable, while $32(24.2 \%)$ responded to it as being unsuitable.

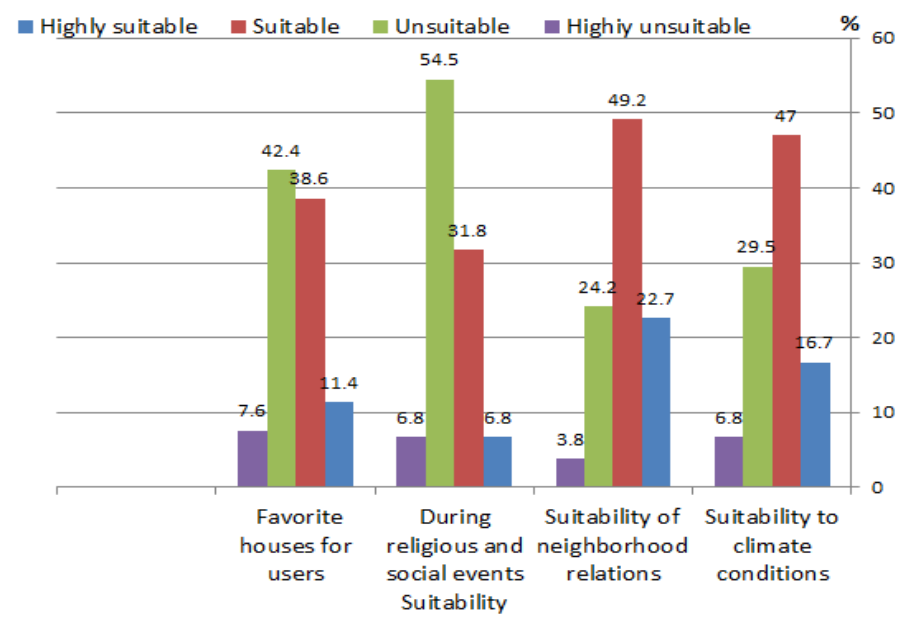

Figure 16. House suitability factor

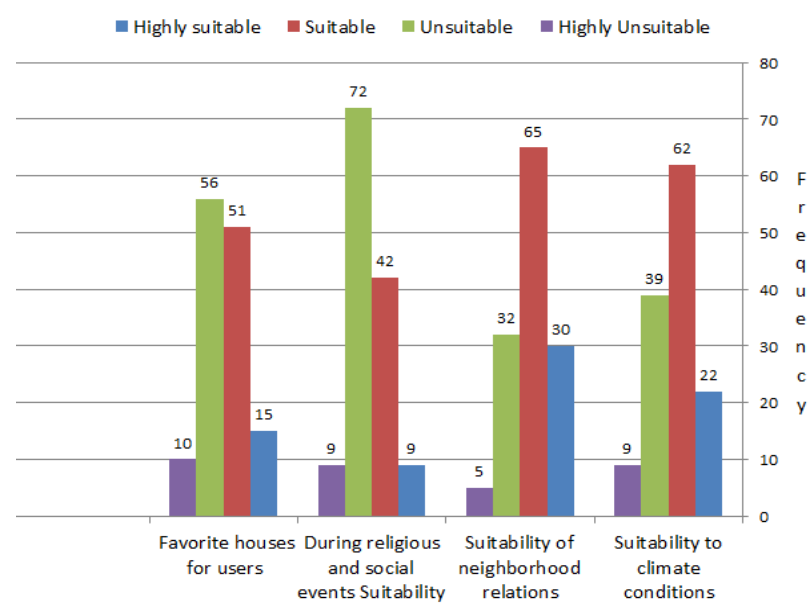

Figure 17. Frequency of house suitability 


\section{Descriptive Statistics of Environmental Suitability}

The scale was used for measuring the use of environmental suitability were (highly suitable, suitable, unsuitable and highly dissatisfied), and the Figure 18 illustrates the results of the frequency and percentages of the environmental suitability of houses factor.

It can be observed that most of the respondents (ca. $47 \%$ to $53.8 \%$ ) deemed their houses unsuitable and $16.7 \%$ to $33.3 \%$ deemed their houses highly dissatisfied. The effect of means for healing factor had 71 respondents (53.8\%) deeming their houses unsuitable and 22 respondents (ca. 16.7\%) indicating their homes as being highly dissatisfied. In total, more than $70 \%$ of users were dissatisfied with their houses. The factor of sunlight inside users' houses had 70 respondents (ca. 53\%) indicating unsuitability and $36(27.3 \%)$ deeming their situation highly dissatisfied. Suitability to climate conditions had 84 respondents (ca. 63.7\%) deeming their situations unsuitable and highly dissatisfied.

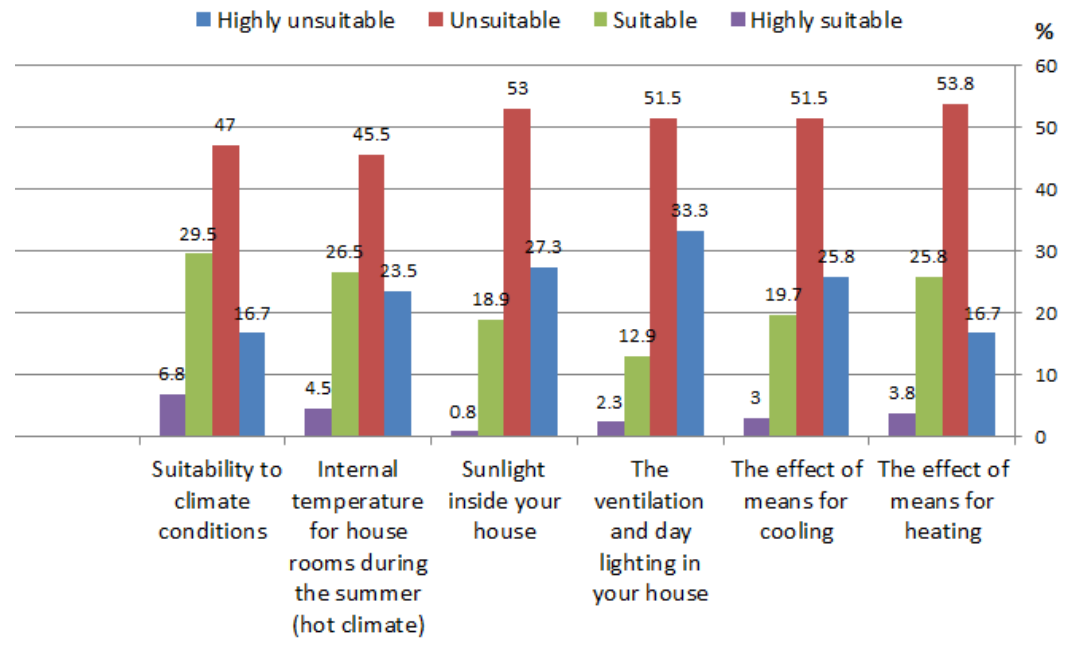

Figure 18. House environmental suitability

\section{Descriptive Statistics for Payment Suitability}

The scale was used for measuring use of for payment suitability were (highly suitable, suitable, unsuitable and highly unsuitable), and the Figure 19 presents the results of the payment of bills suitability for users' houses and shows the suitability of electricity bill services as being the highestranking with $48.5 \%$ of respondents deeming payment of electricity services unsuitable and $13.6 \%$ deeming it highly unsuitable, while $32.6 \%$ of respondents deemed payment of electricity bills suitable and 5.3\% highly suitable. The payment of water and communication services bills had the same ranking of suitability such that $43.2 \%$ of respondents found these factors suitable and $38.6 \%$ found them unsuitable, while $9.1 \%$ found them highly unsuitable as well as $9.1 \%$ highly suitable. 


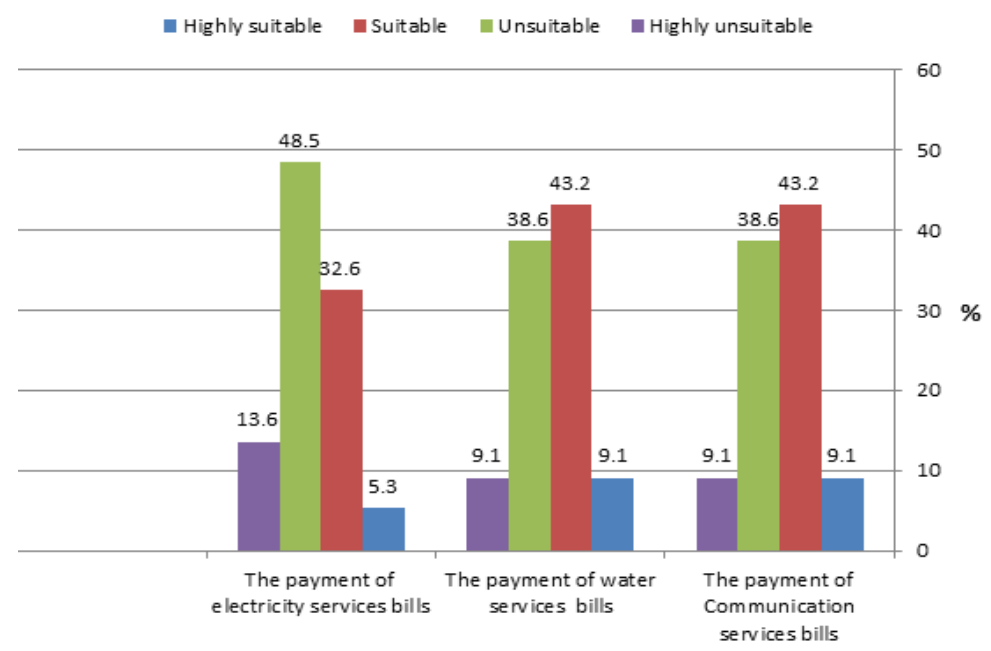

Figure 19. Suitability of bill payments

\section{Testing the relationships between suitability and satisfaction sub-dimensions using}

\section{Pearson Correlations}

Table 6 shows the correlations between suitability and satisfaction sub-dimensions. Environmental suitability shows positive correlations with every other sub variable, with values ranging between 0.195 and 0.482 , and $\mathrm{p}<0.05$.

Table 5. Correlations between suitability and satisfaction sub-dimensions

\begin{tabular}{|c|c|c|c|c|c|}
\hline & & $\begin{array}{c}\text { Service } \\
\text { availability } \\
\text { satisfaction }\end{array}$ & $\begin{array}{c}\text { Social } \\
\text { satisfaction }\end{array}$ & $\begin{array}{c}\text { Social } \\
\text { suitability }\end{array}$ & $\begin{array}{c}\text { Environmental } \\
\text { Suitability }\end{array}$ \\
\hline \multirow{3}{*}{$\begin{array}{l}\text { Social } \\
\text { satisfaction }\end{array}$} & $\begin{array}{l}\text { Pearson } \\
\text { Correlation }\end{array}$ & $0.297^{* *}$ & 1 & & \\
\hline & Sig. (2-tailed) & 0.001 & & & \\
\hline & $\mathrm{N}$ & 132 & 132 & & \\
\hline \multirow{3}{*}{ Social Suitability } & $\begin{array}{l}\text { Pearson } \\
\text { Correlation }\end{array}$ & $0.234^{* *}$ & $0.271^{* *}$ & 1 & \\
\hline & Sig. (2-tailed) & 0.007 & 0.002 & & \\
\hline & $\mathrm{N}$ & 132 & 132 & 132 & \\
\hline \multirow{3}{*}{$\begin{array}{l}\text { Environmental } \\
\text { Suitability }\end{array}$} & $\begin{array}{l}\text { Pearson } \\
\text { Correlation }\end{array}$ & $0.482^{* *}$ & $0.336^{* *}$ & $0.341^{* *}$ & 1 \\
\hline & Sig. (2-tailed) & 0.000 & 0.000 & 0.000 & \\
\hline & $\mathrm{N}$ & 132 & 132 & 132 & 132 \\
\hline \multirow{3}{*}{$\begin{array}{l}\text { Payment } \\
\text { Suitability }\end{array}$} & $\begin{array}{l}\text { Pearson } \\
\text { Correlation }\end{array}$ & 0.152 & $-.152 \mathrm{o}$ & $0.219^{*}$ & $0.195^{*}$ \\
\hline & Sig. (2-tailed) & 0.082 & 0.519 & 0.012 & 0.025 \\
\hline & $\mathrm{N}$ & 132 & 132 & 132 & 132 \\
\hline \multicolumn{6}{|c|}{ ** Correlation is significant at the 0.01 level (2-tailed). } \\
\hline \multicolumn{6}{|c|}{$*$ Correlation is significant at the 0.05 level (2-tailed). } \\
\hline
\end{tabular}




\section{Groups Variance Analysis (ANOVA)}

The analysis includes knowing how some parts of the house are used by the family for different times and seasons by using questionnaire scales and it is summarized as follows:

\section{- Use of balconies in the house by users during different times of the day}

The scale was used for measuring the use of balconies by the households during different times of the day were (always, often, sometimes and rarely), and the Figure 20 shows the results for the use of balconies at different times. Balconies always being used in the morning scored highest at $43.8 \%$ of respondents followed by balconies often being used in the morning at $28.8 \%$. The figure illustrates that most users would rarely use their balconies during the night $(60.6 \%)$ and $25 \%$ would sometimes use them at night. The use of balconies during the evening ranked third with users sometimes using their balconies (39.4\%) and rarely using them, at $25.8 \%$. The last item in the ranking was the use of balconies during the afternoon during which time $37.1 \%$ of respondents sometimes and $34.8 \%$ rarely used their balconies.

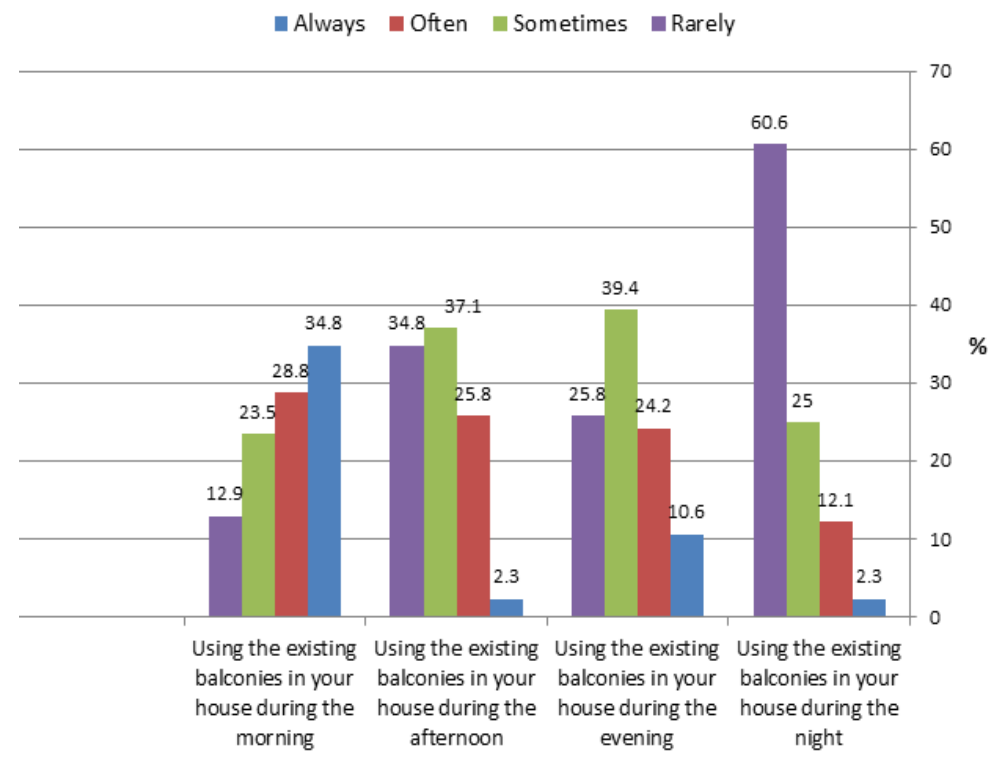

Figure 20. Use of balconies during different times of the day

\section{- Use of balconies for different purposes}

The scale was used for measuring the use of balconies by the household's different purposes were (always, often, sometimes and rarely), and the Figure 21 illustrates the questionnaire results for the factor of purposes of using balconies in houses. It is observed that $65.2 \%$ of respondents would always use their balconies to dry laundry, and the ranking second was $28.8 \%$ of respondents would often use their balconies for the same purpose. The figure shows that most users always used their balconies for ventilation at $41.7 \%$ and $39.4 \%$ often use balconies for ventilation. $32.6 \%$ rarely use their balconies for rest and recreation and $10.6 \%$ of respondents always did so. For the use of the balconies for other purposes (for storage, like children's play areas, etc.), $47 \%$ rarely did so and $28.8 \%$ occasionally did so. 


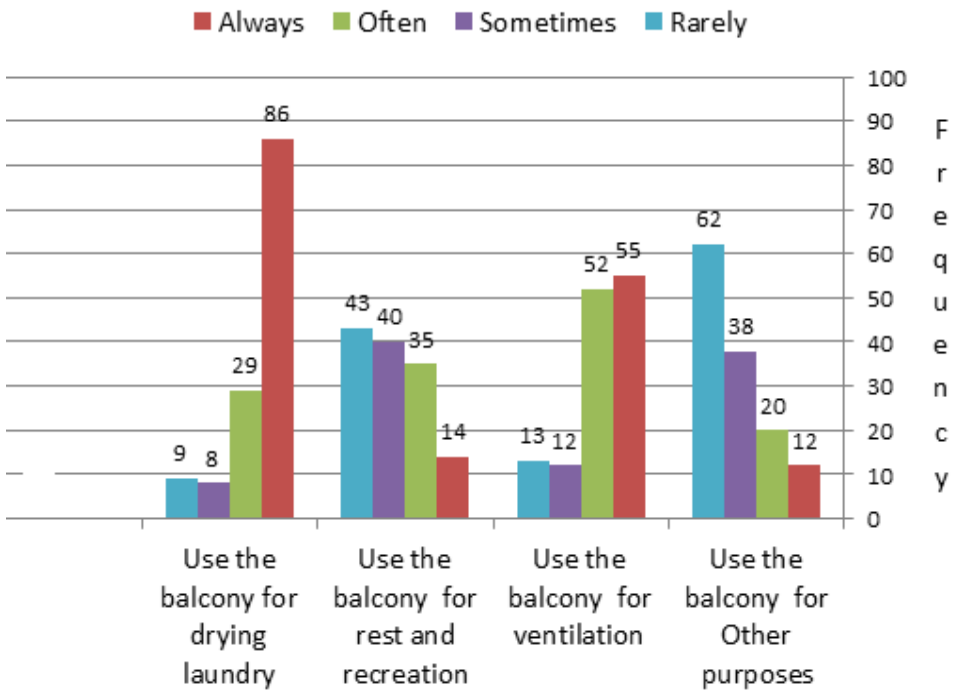

Figure 21. Balcony usage for a different purpose

\section{- Using windows for ventilation during different times of the day}

The scale was used for measuring the use of windows for ventilation during different times of the day were (always, often, sometimes and rarely), and the Figure 22 presents the results for use of windows for ventilation. It can be observed that the use of windows for ventilation at night had the highest-ranking at a rate of $67.4 \%$ for rare use by respondents, followed by windows always being used by $65.2 \%$ of users for ventilation in the morning. $36.4 \%$ of respondents rarely used windows for ventilation in the afternoon and $29.5 \%$ sometimes did so, and for evening use, $33.3 \%$ rarely did so and $31.8 \%$ sometimes did so.

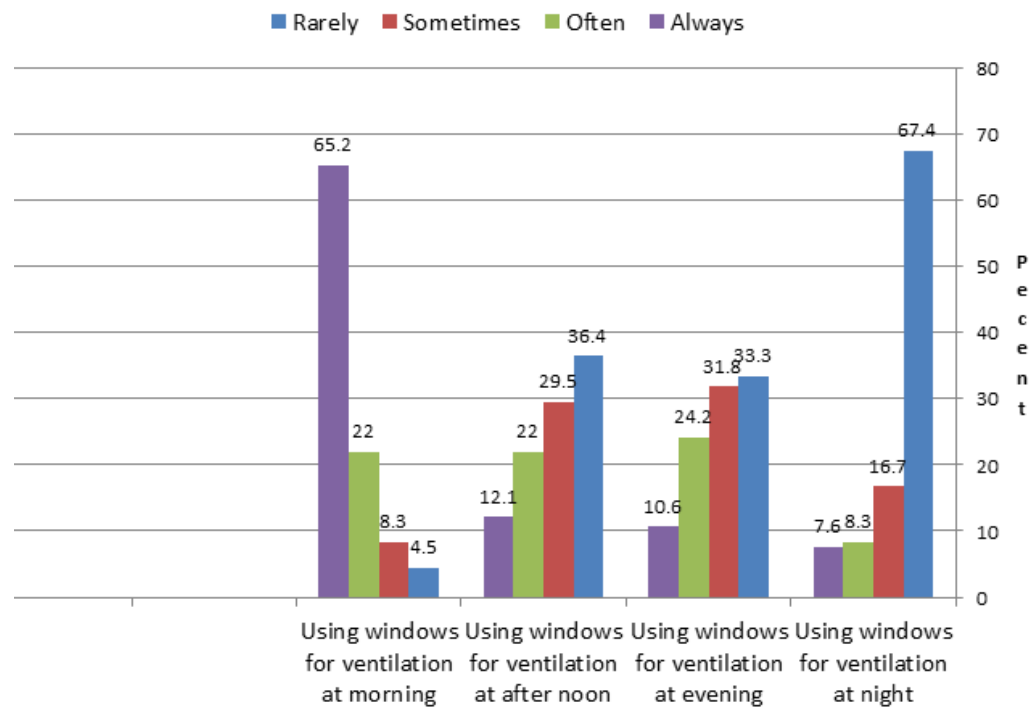

Figure 22. Use of windows for ventilation during different times of the day 


\section{- Means of cooling and heating in users' houses}

The scale was used for measuring the use of means of cooling and heating in users' houses were (always, often, sometimes and rarely).

\section{- In the summer: - Natural ventilation (Ventilation and Cooling)}

Figure 23 illustrates the results for the means of cooling of users' houses in the summer, showing that air-conditioning ranked highest at $72 \%$ of respondents who would always use the $\mathrm{AC}$ for cooling followed by natural ventilation often being used by $31.1 \%$. The use of fans as a means of cooling ranked highest for its rarely being used by $88.6 \%$ of the respondents and $87.1 \%$ of the respondents using roof fans.

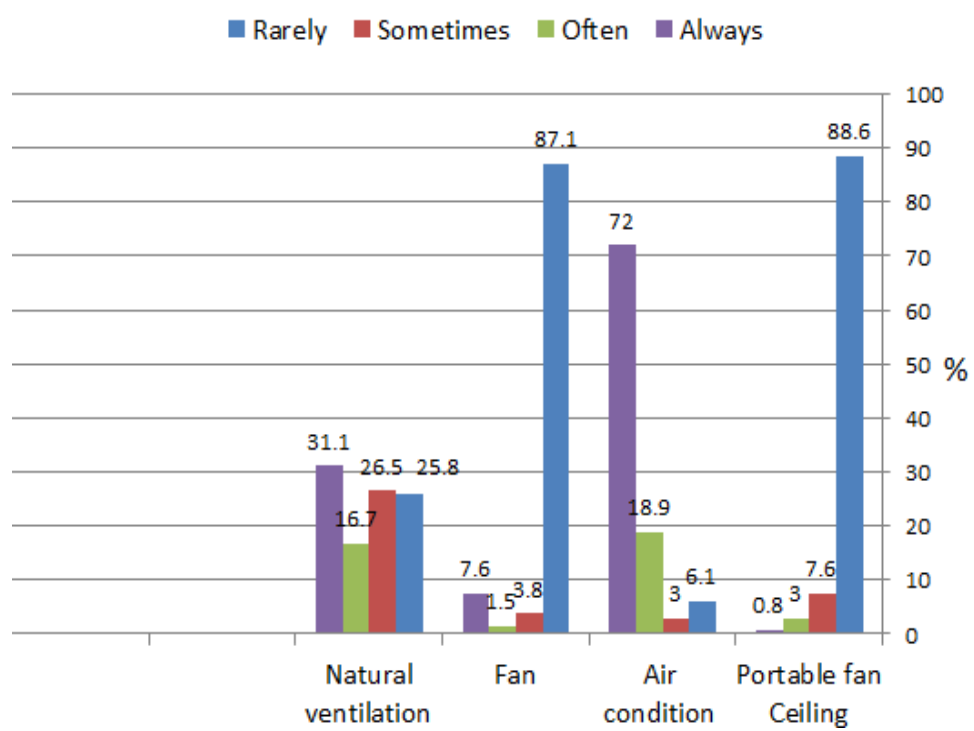

Figure 23. Means of using cooling in the summer

\section{- Heating in the winter}

The scale was used for measuring the use of means of cooling and heating in users' houses were (always, often, sometimes and rarely). Figure 24 illustrates the results of the means of winter heating of users. It can be observed that the fireplace of kerosene use ranked highest with $97 \%$ of the respondents always using the fireplace of kerosene and rarely at the same time, followed by the use of coal fireplace by $84.8 \%$ of the respondents. An electric fireplace was always used by $56.1 \%$ of the respondents and $35.6 \%$ of the respondents would use air conditioners. 


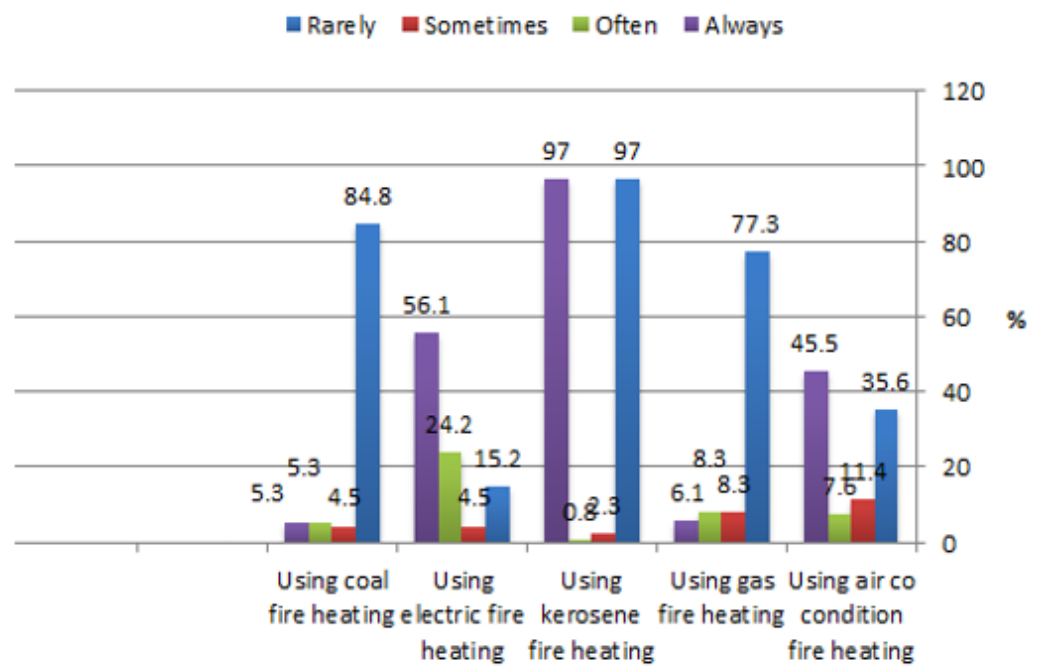

Figure 24. Means of heating houses during the winter

\section{- Precautions are taken by users to prevent the entry of excessive sunlight}

The scale was used for measuring the use of precautions taken by the users to prevent the entry of excessive sunlight were (highly suitable, suitable, unsuitable and highly unsuitable). Figures 25 and 26 shows the results for precautions taken by users to prevent the entry of excessive sunlight into their houses. Always using blinds had the highest ranking of 94 respondents $(71.2 \%)$, followed by curtains by 41 respondents (31.1\%). Climbing plants were the highest rare usage by 122 respondents $(92.4 \%)$.

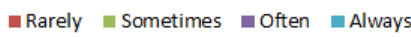

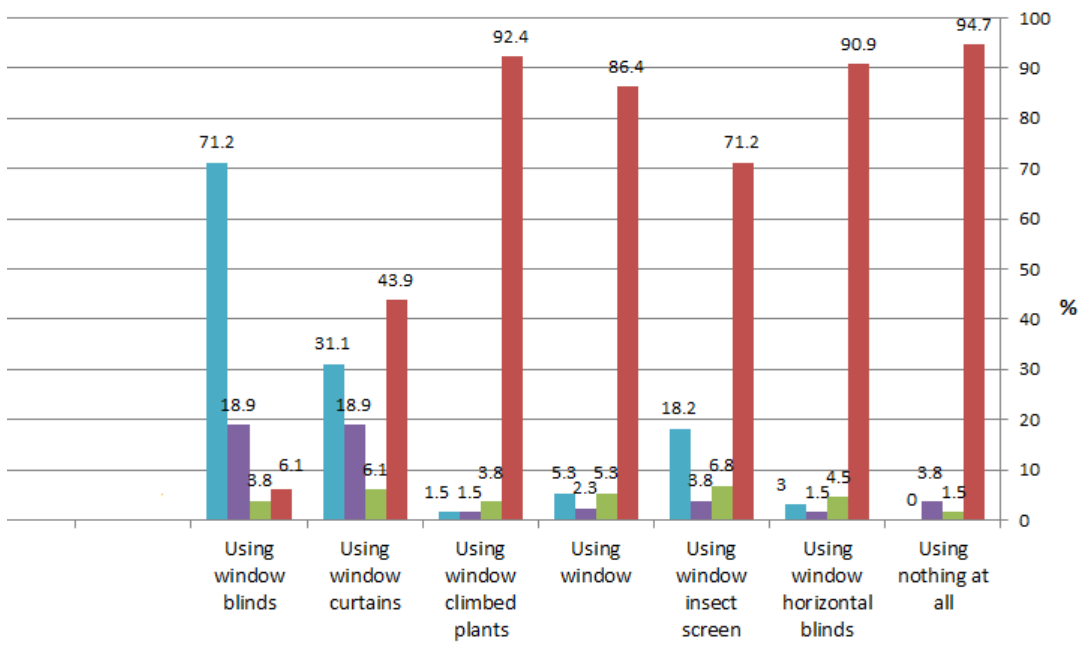

Figure 25. Use of different window blinds 


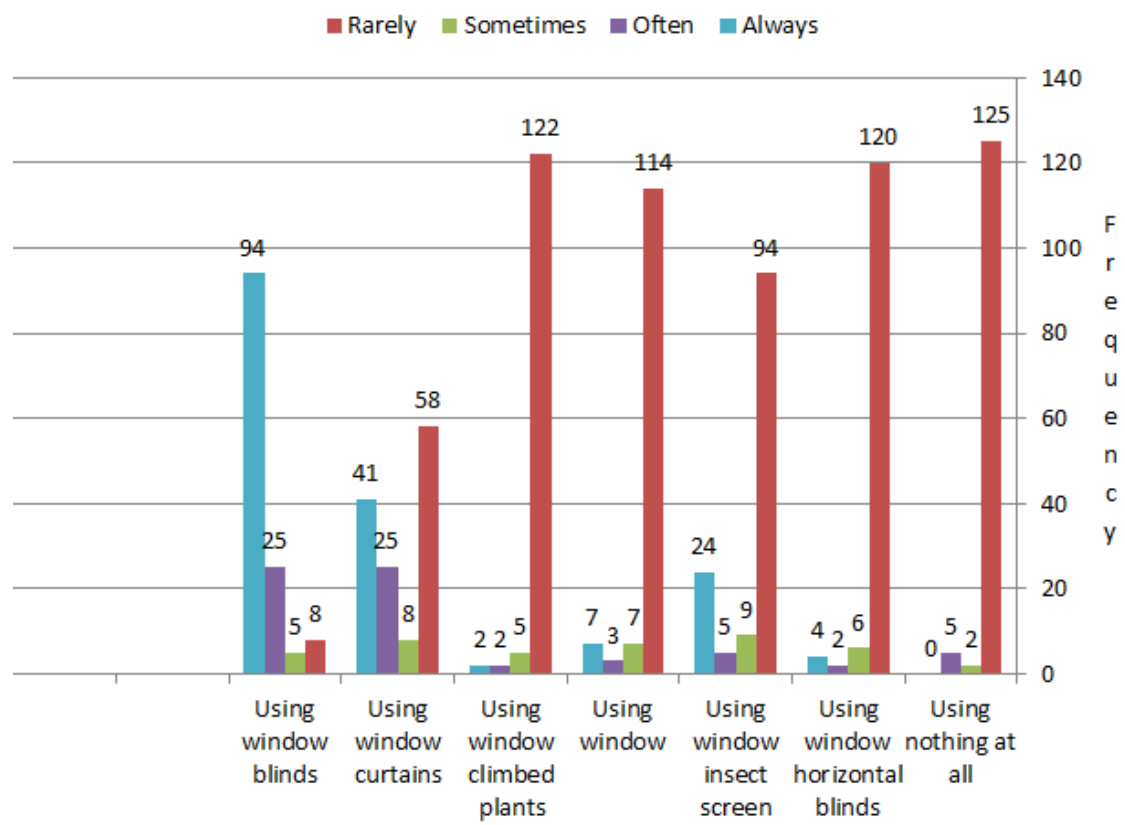

Figure 26. Frequency of use of different window blinds

- The extent to which users agree to design their houses in the future in terms of the types of houses in which users prefer to live:

Three types of houses (modern villa, a detached traditional courtyard, and apartments in an apartment building) were identified to find the preferred type for the inhabitancies, and they were as follows:

\section{- Detached Traditional Courtyard House}

Figures 27 and 28 show the results of the types of houses in which users prefer to live. The modern villa was the highest-ranking with 77 respondents $(58.3 \%)$ finding this type of house highly agreeable, followed by 52 respondents (39.4\%) agreeing. 47 users (35.6\%) highly agreed with preferring to live in detached traditional courtyard houses. 62 respondents $(47 \%)$ highly agreed with a preference for an apartment in apartment building, and 33 (25\%) disagreed. Additionally, 62 respondents (47\%) highly disagreed about living in an apartment. 


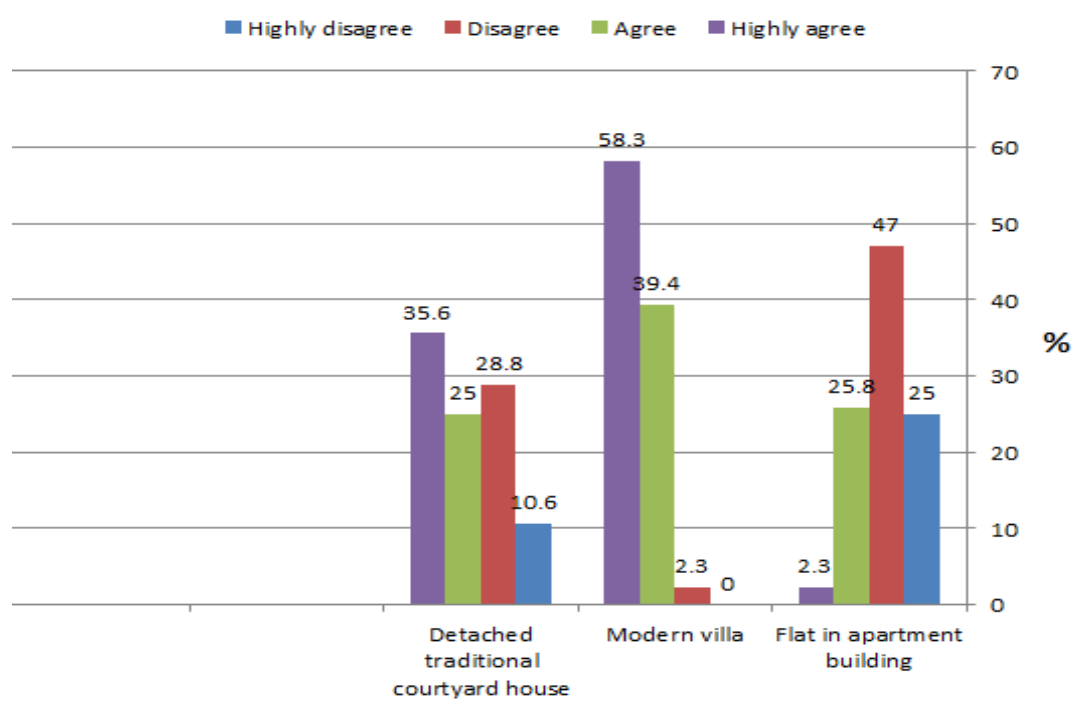

Figure 27. Housing type preferring

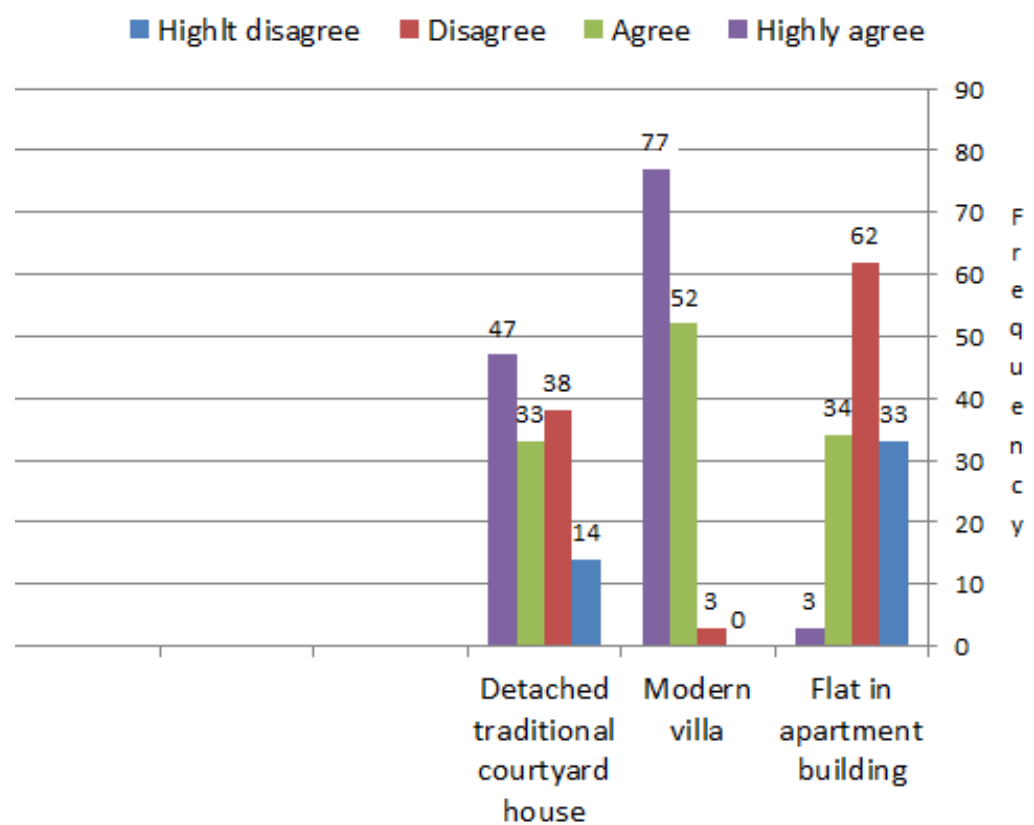

Figure 28. Frequency of housing type preference

\section{- Reasons for some types of a house being preferred by users}

Figures 29 and 30 show the reasons for users preferring a particular type of house. The highestranking reason for the suitability was Libyan family social life, which was deemed by 126 respondents $(95.5 \%)$ as being suitable. The factor of being more comfortable for the Libyan climatic conditions had 117 respondents $(88.6 \%)$ who agreed about it being more comfortable for 
Libyan climatic conditions. The factor of special separate spaces for females and males scored 79 respondents $(59.8 \%)$ highly disagreeing.

nighly disagree $\quad$ Disagree $\quad$ Agree $\quad$ Highly agree

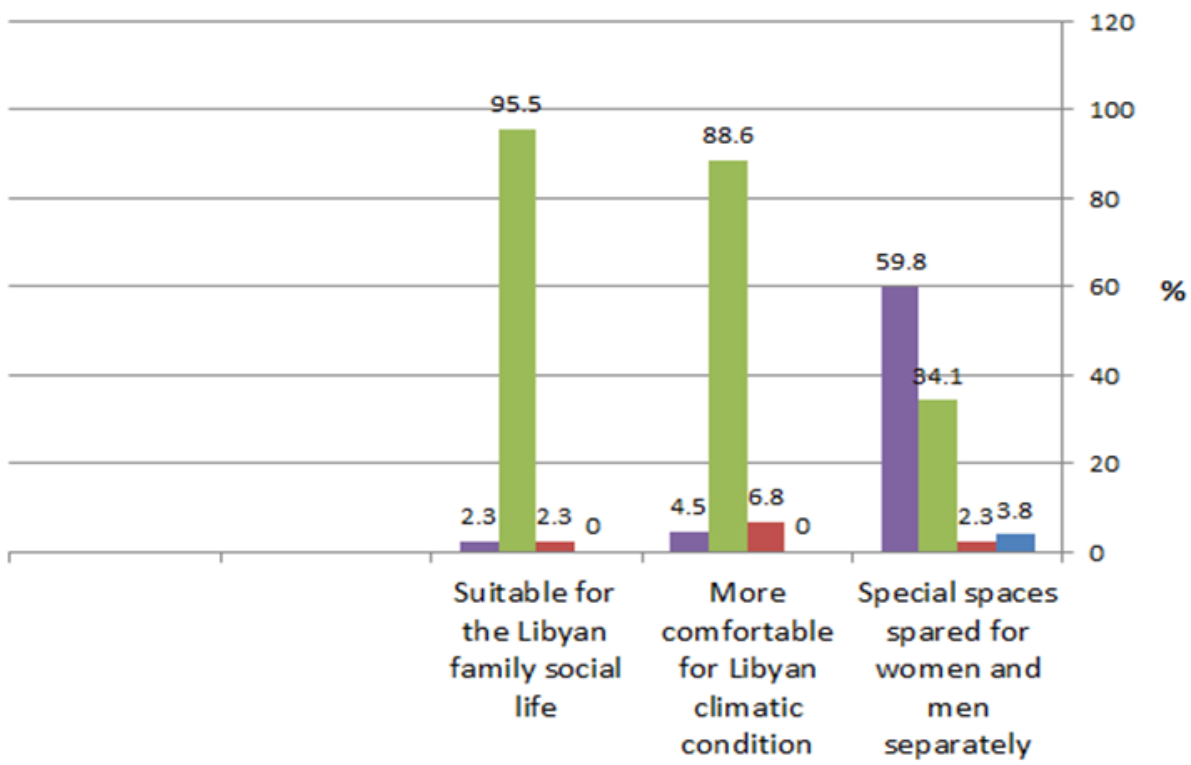

Figure 29. Reasons for users' housing type preference

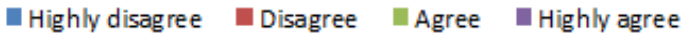

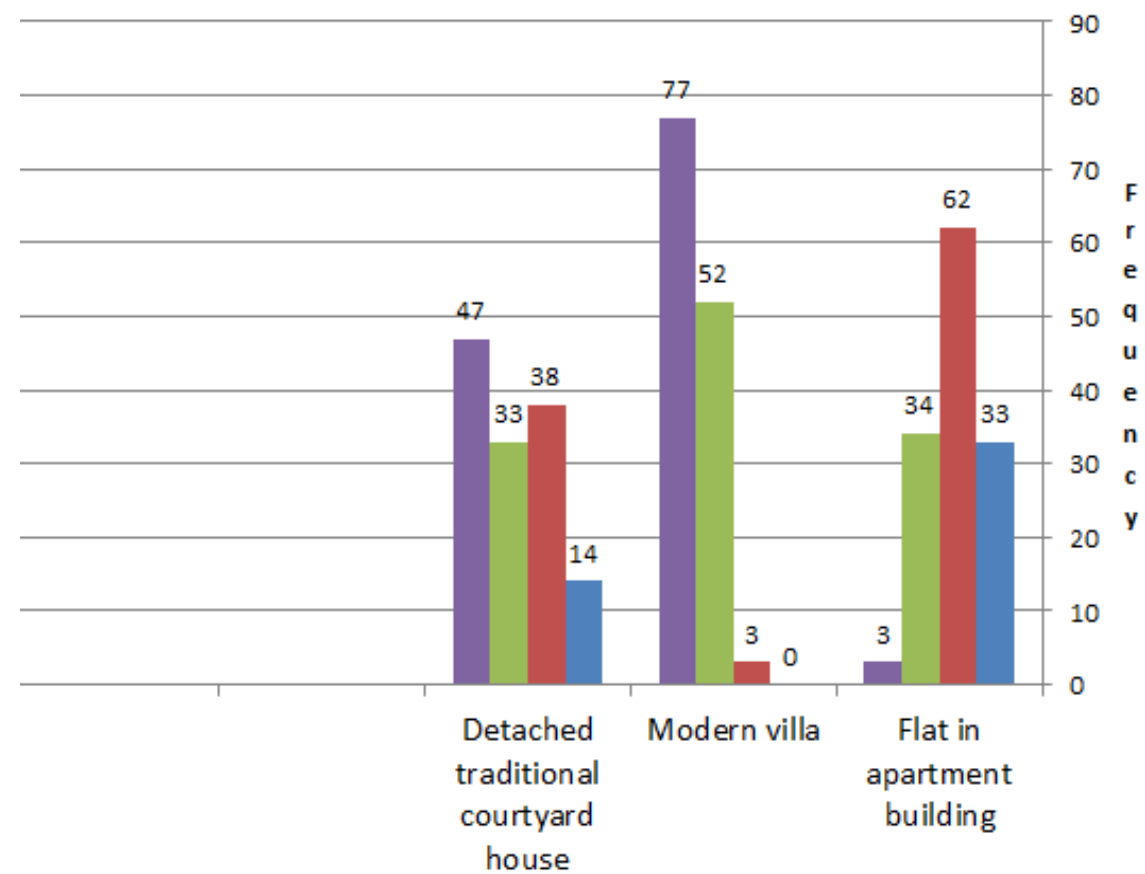

Figure 30. Frequency of housing type preference 


\section{- The modifications made by users and the most and least pleasing sides of houses} according to users' opinions

Figures 31 and 32 show the results of modifications made by users in their houses. Ranking first was the addition of areas for some spaces, which had the highest ranking of 75 (56.8\%), followed by changes made for guest spaces by 28 respondents $(21.2 \%)$. The third-ranking pertained to modifications made for living spaces, which were made by 16 respondents $(12.2 \%)$, while ranking fourth was modifications made for sleeping spaces by 13 respondents $(9.8 \%)$. The most pleasing side of the houses were the living spaces, which had the highest ranking of 59 respondents $(44.7 \%)$, while the least pleasing sides of their houses were sleeping spaces, which were the highest-ranking at 50 respondents $(37.9 \%)$.

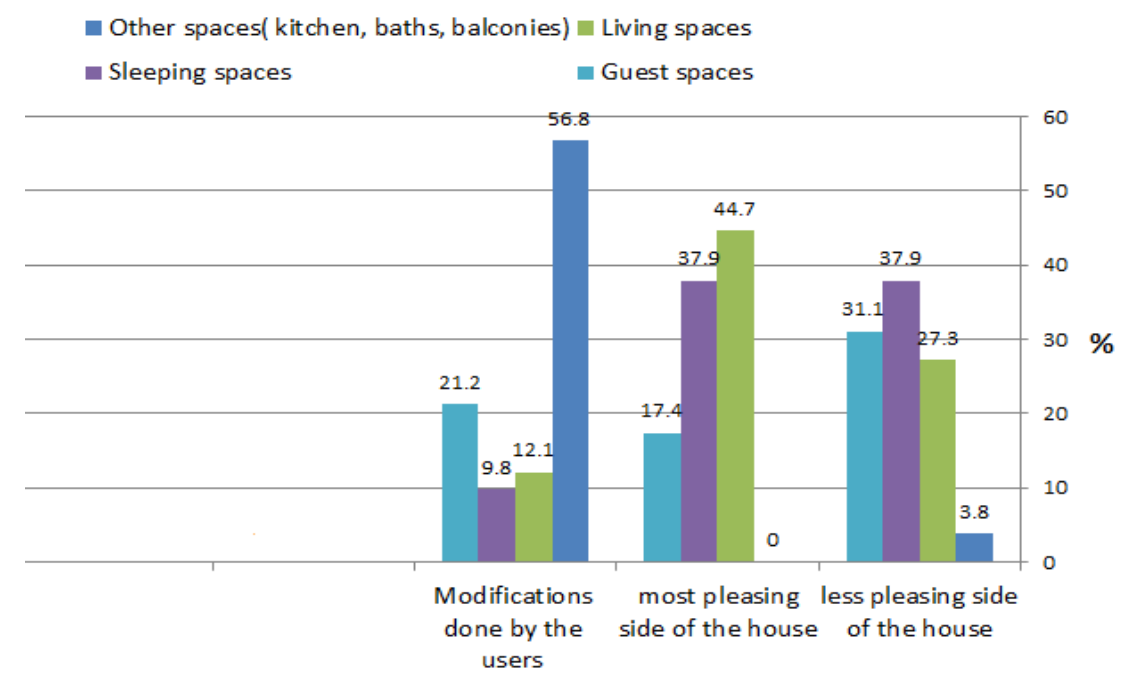

Figure 31. Modifications, most to least pleasing

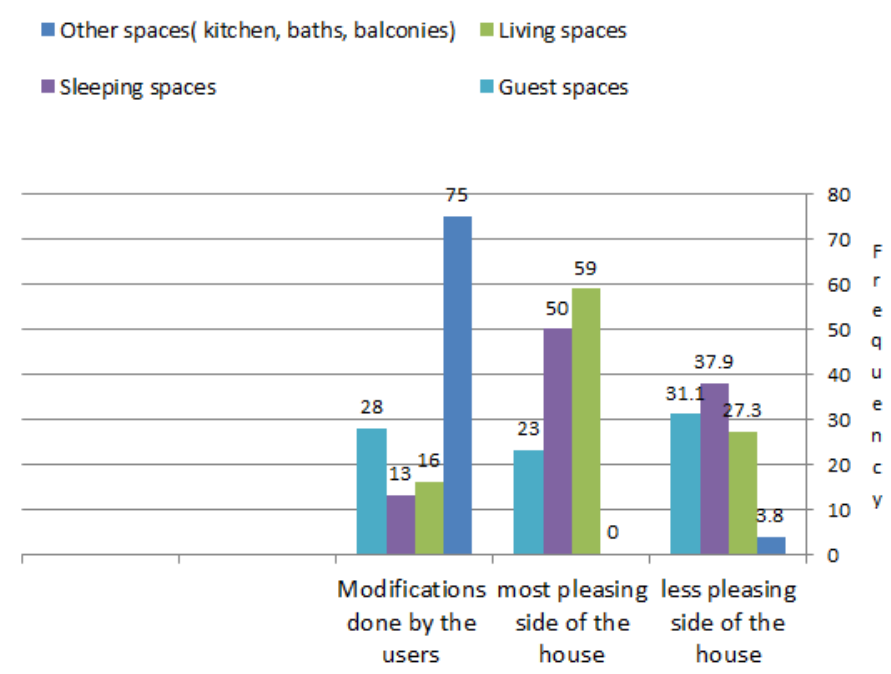

Figure 32. Frequency of modifications, most to least pleasing 
And the following Figures 33 and 34 illustrate examples of the modifications made by users for some apartment buildings in sites of the case study.

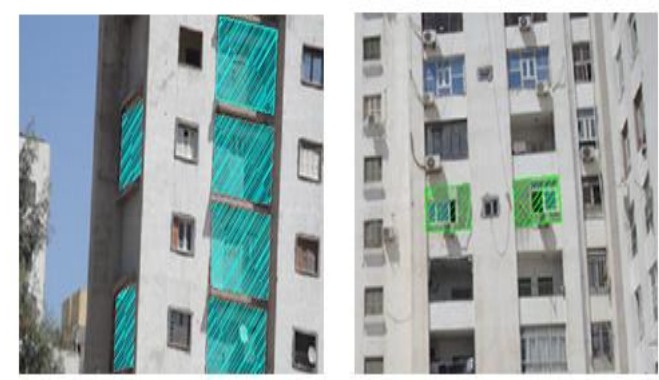

Closed the balconies by users- Air-Port Road Housing project

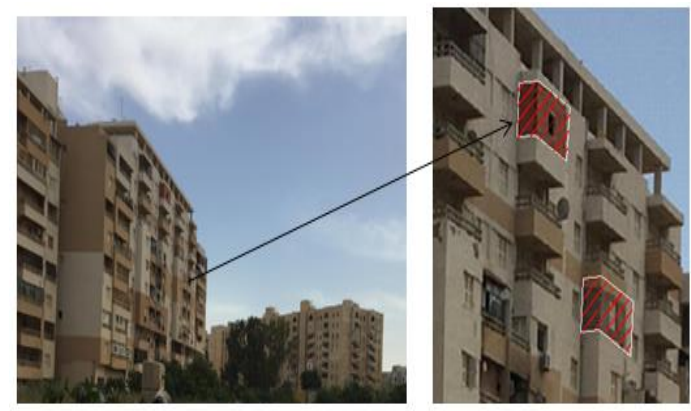

Closed the balconies by users- EL-Hadba Housing project

Figure 33. Modifications made by users (Source: O. A. Alameen archive)

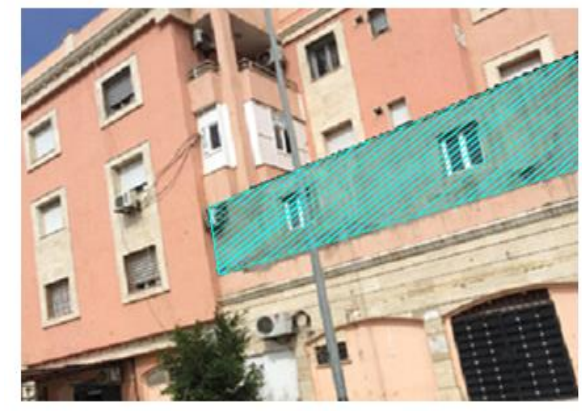

Closed the balconies by users - Ghot Ash - Ahaal Housing project

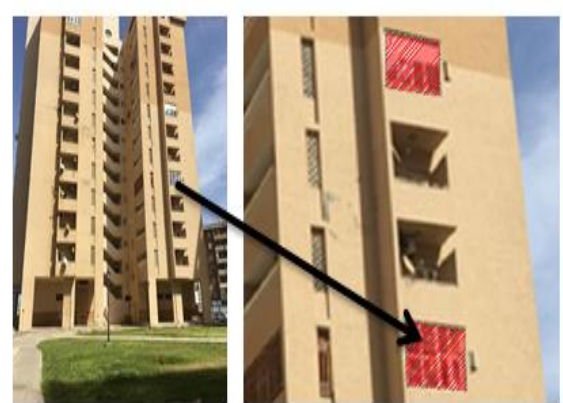

Closed the balconies by users Souq- Atolata (North) Housing Projec

Figure 34. Modifications made by users (Source: O. A. Alameen archive)

\section{GENERAL EVALUATION OF THE RESULTS}

The evaluation of the user questionnaire in this paper is a result of the analyses of users' questionnaire information. This questionnaire consisted of five main axes with the main headings as follows:

- User satisfaction;

- Suitability of the user's house;

- The usability of some spaces at home for the family;

- Future preferences for houses for the user in terms of the type(s) of a house in which this user wishes to live; and 
- The extent to which the user's house requires design modifications to suit the user's needs.

The questionnaire covered all of the abovementioned axes for a sample of housing users from four sites of the case study. Where it was noted that there are no differences between the sites, with the exception of the Souq Atolata (north) site, it is considered a fully completed residential neighbourhood, and the rest suffers from neglect and lack of completion of the infrastructure. So, the findings divided as follows:

The user survey on the frequency and percentage rate of opinions of users' houses for strengthening social relationships revealed that $75 \%$ of respondents were not satisfied or highly dissatisfied, while of the remaining respondents, $25 \%$ were satisfied and highly satisfied.

- The availability of services for users dimension showed that for public services, most of the respondents were not satisfied at a rate of $40.2 \%$, with those highly dissatisfied at a rate of $13.6 \%$ of total respondents. For the availability of using common spaces (staircases, elevators), $39.4 \%$ of respondents were satisfied $24.2 \%$ were highly dissatisfied.

- The availability of public transportation was the third rankings such that $31.8 \%$ were highly dissatisfied and $27.3 \%$ were not satisfied.

- Availability of public utilities ranked fourth revealing that $35.6 \%$ of the total respondents were not satisfied and that $18.9 \%$ were dissatisfied rate. The availability of commercial services was the last ranking revealing that $7.6 \%$ of total respondents were highly dissatisfied, and $33.3 \%$ were not satisfied.

- Approximately $54.5 \%$ of the respondents indicated that their houses were unsuitable during religious and social events and approximately $6.8 \%$ of the respondents stated that their houses were highly unsuitable.

- External noise within the houses was deemed unsuitable by 63 of the respondents $(47.7 \%)$ and $22(16.7 \%)$ stated this dimension as being highly unsuitable.

- With regard to being favourite houses for users, $42.4 \%$ of respondents deemed their houses unsuitable and approximately $7.6 \%$ thought their houses were highly unsuitable.

- For privacy within houses, 50.8\% indicated that their houses were suitable, but approximately $25 \%$ of respondents deemed that privacy within their houses was unsuitable.

- For the suitability of the neighbourhood relations factor, $40.2 \%$ deemed it to be suitable, while $24.2 \%$ of respondents deemed it as being unsuitable.

- Between $47 \%$ and $53.8 \%$ of the respondents stated that their houses were environmentally unsuitable and $16.7 \%$ to $33.3 \%$ said that their houses were highly unsuitable. For example, $53.8 \%$ stated that the means for heating were unsuitable and, $16.7 \%$ found them highly unsuitable. In total, more than $70 \%$ of users were unsatisfied with their houses in terms of environmental suitability. 
- The results for the suitability of payment of bills for users indicate that $48.5 \%$ of respondents deemed the payment of electricity services unsuitable, 13.6\% deemed them highly unsuitable, while $32.6 \%$ of respondents were indicating that the payment of electricity bills was suitable and only $5.3 \%$ though they were highly suitable.

- At different times of the day, it is shown that $43.8 \%$ of respondents always used their balconies during the morning, followed by $28.8 \%$ often using their balconies in the morning. Most respondents $(60.6 \%)$ rarely used their balconies during the night, and $25 \%$ occasionally use their balconies at night. Using balconies during the evening ranked third.

- $94 \%$ of respondents used their balconies for drying laundry, but $6 \%$ used their balconies for rest and recreation, $32.6 \%$ rarely used them for this purpose, whereas $10.6 \%$ always used them for rest and relaxation. For other uses (such as for storage or as a children's play area), $47 \%$ of the respondents would rarely use the balconies, and $28.8 \%$ would occasionally use their balconies for other purposes.

- $65.2 \%$ of users always used windows for ventilation in the morning and $29.5 \%$ sometimes did so. For the afternoon, $36.4 \%$ stated they rarely did so. For this reason, air-conditioning was the highest-ranking at $72 \%$ of respondents always using an $\mathrm{AC}$ for cooling.

- It was found that $97 \%$ of the respondents always used kerosene for heating and $84.8 \%$ would use coal for heating.

- The use of window blinds to prevent the entry of excessive sunlight ranked highest at $71.2 \%$ of the respondents.

- The types of houses in which users prefer to live were, ranking first, the modern villa, which was the highest-ranking preference at a rate of $97.7 \%$ of respondents, and the separate traditional courtyard house at $60.6 \%$ of respondents. Apartments in apartment buildings were ranked third at a rate of $28.1 \%$ of users. These rankings for housing type preferences are due to Libyan family social life.

- For modifications made by users in their houses, ranking first at $56.8 \%$ of users was the adding of areas for some spaces, followed by guest spaces at $21.2 \%$, while modifications were made for sleeping spaces at a rate of $9.8 \%$.

- The more pleasing side of $44.7 \%$ of the respondents' houses was used as living spaces and $37.9 \%$ of the respondents would use the less pleasing sides of their houses as sleeping spaces. 


\section{MAJOR FINDINGS AND RESULTS}

The major findings in this paper are a result of the analyses of information from the user questionnaire, which consists of five main axes with the main headings:

- User satisfaction

- Suitability of the users' houses

- The use of some spaces in the users' house

- Future preferences for housing for the user in terms of the type of house in which the user wishes to live

- The extent to which users' houses required modifications in design to suit user requirements

As a result, the questionnaire covered the entire above axes for a sample of housing users from four sites of the case study, and the findings were divided as follows:

\section{Social Services Results}

1. Questions on the availability of services illustrate that most of the respondents were unsatisfied, a rate of $63.6 \%$ of total respondents.

2. The respondents were unsatisfied with the availability of public transportation at a rate of $59.10 \%$.

3. 59.1\% of total respondents were satisfied with the availability of commercial services, whereas $41.1 \%$ were unsatisfied.

4. It was shown that 72 of the total respondents (61.3\%) deemed their houses as being unsuitable during religious and social events, and 38.7\% indicated that their houses were suitable during religious and social events.

5. $64.4 \%$ of respondents stated that external noise within the house was unsuitable, and $35.6 \%$ deemed external noise within their houses as suitable.

6. With regard to privacy within houses, 67 of the respondents $(50.8 \%)$ found the privacy within their houses suitable. However, $33(25 \%)$ deemed their houses as being unsuitable for privacy.

7. At a rate of $71.9 \%$, the respondents stated that their houses were suitable for neighbourhood relations, whereas $28.8 \%$ stated the contrary (unsuitable).

\section{Environmental Results}

1. The survey revealed that $47 \%$ to $53.8 \%$ of the respondents found their houses environmentally unsuitable and $16.7 \%$ to $33.3 \%$ found their houses highly unsuitable. 
2. 93 respondents $(70.5 \%)$ stated that the effect of means for heating as being unsuitable.

3. At a rate of $80.3 \%, 106$ respondents stated that the sunlight inside their houses was unsuitable, and regarding suitability to climate conditions, 84 respondents $(63.7 \%)$ that sunlight was unsuitable inside their houses.

4. $72 \%$ of the respondents ranked air conditioning the highest.

5. $65.2 \%$ of the respondents stated that they used windows for ventilation in the morning and $67.4 \%$ stated they rarely used windows at night. $31.1 \%$ stated they used natural ventilation.

6. The use of kerosene for heating ranked highest at $97 \%$, followed by the use of coal for heating at $84.8 \%$.

7. Precautions taken by users to prevent the entry of excessive sunlight inside their houses using windows blinds had the highest ranking of 94 respondents $(71.2 \%)$.

\section{Economical Results}

1. $62.10 \%$ of respondents found the electricity payment system and services bills to be unsuitable, while $37.9 \%$ deemed the payment of electricity services bills as being unsuitable.

2. Payments of water services and communication services bills had the same suitability rankings with $52.3 \%$ of total respondents finding them suitable and $47.7 \%$ finding the payment of water services bills unsuitable.

\section{Architectural Results}

1. For the use of balconies at different times of the day, it was observed that mornings always had the highest rate of use by $34.8 \%$ of the respondents and the second-highest rate of use was by $28.8 \%$ of respondents. $37.10 \%$ of the respondents sometimes used the balconies during the afternoon, while $60.6 \%$ rarely used the balconies at night.

2. The use of the balconies for a different purpose in their houses noted had the highestranking at $65.2 \%$ of respondents who would use their balconies to dry laundry. $43 \%$ of the respondents rarely used their balconies for rest and recreation; however, 55\% used their balconies for ventilation. $62 \%$ rarely used their balconies for other purposes (such as for storage as a children's play area).

3. At a rate of $58.3 \%, 77$ respondents stated that they preferred to live in modern villas, while detached traditional courtyard houses were preferred by 47 respondents $(35.6 \%)$.

4. With regard to housing type preferences, the results indicate that houses were preferred more suitable for Libyan family social life; this had the highest ranking of 126 respondents $(95.5 \%)$. 
5. Modifications made by the users in their houses, such as adding more space, had the highest ranking, numbering 75 respondents $(56.8 \%$ of the respondents). The second-ranking was guest spaces at a rate of $21.2 \%$ of respondents.

6. The more pleasing side of the house being used for living space had the highest ranking of 59 respondents $(44.7 \%)$. The less pleasing side of the house was used for sleeping spaces, the highest-ranking of which was 50 respondents $(37.9 \%)$ of respondents.

\section{CONCLUSION}

\section{Guidelines for Sustainable Housing}

Implementation of the proposed model related to the mechanism of implementing sustainable housing by issuing the legislation regulating the establishment and development of the Authorities that are specified in the model (Figure 35).

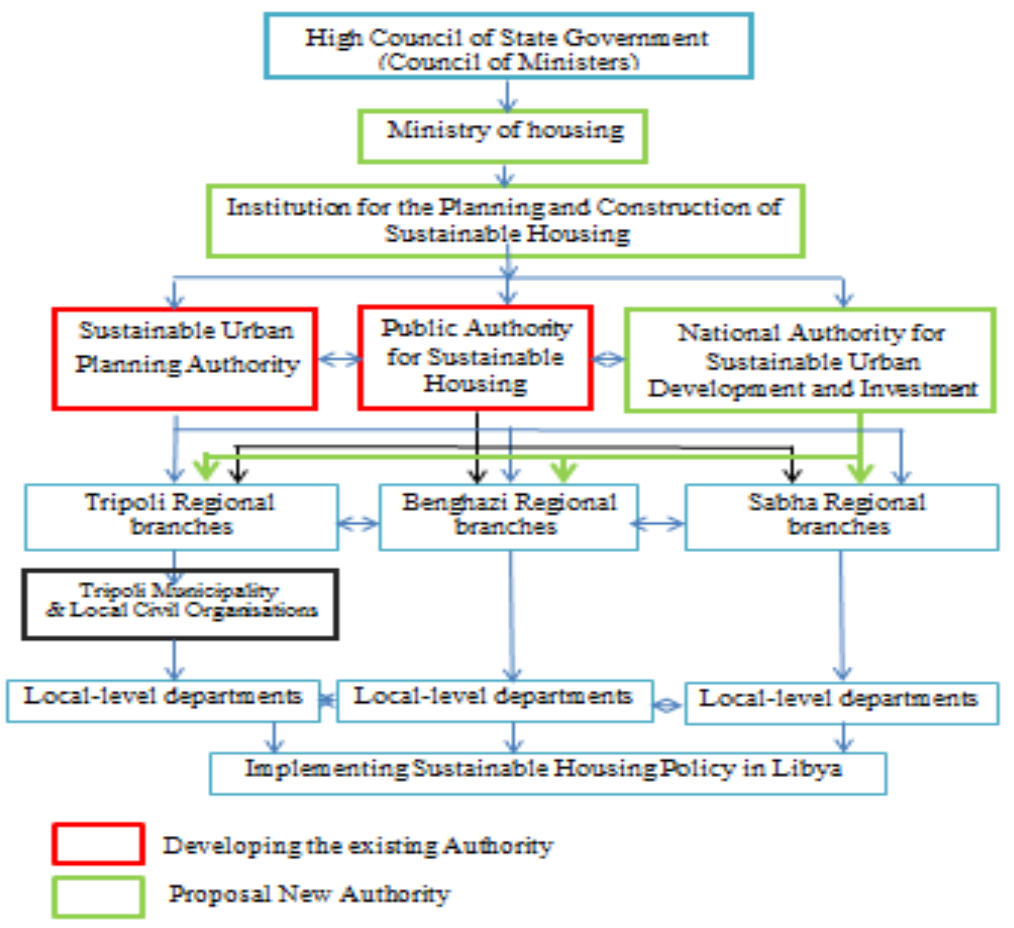

Figure 35. Proposed model for the implementation of the sustainable

For the purpose of achieving user satisfaction and during the design phases of sustainable housing projects, the following are required:

- The needs and desires of users and their economic potential to be taken into account;

- Taking into account the customs and social traditions of the Libyan family; 
- Consideration is given to climatic conditions and the availability of infrastructure (public services and transportation) during the selection of housing project sites;

- Stressing the importance of political and administrative stability of the State in addition to the importance of decentralization and granting wide powers to authorities at regional and local levels;

- Fighting financial and administrative corruption in the State and emphasizing the transparency of decision-making at all levels;

- Encouraging investment in the housing sector for both the public and private sectors as well as encouraging private investment in the green buildings industry;

- Preparation of technical cadres in the field of the implementation of sustainable residential buildings and raising the scientific level in the field of residential sustainability for professionals and workers in the field of sustainable housing implementation.

\section{City of Tripoli Recommendations for the Case Study Sites}

According to the analysis results of the questionnaires, the following is presented as a summary of recommendations concerning the sites of the case study in Tripoli.

\section{General recommendations}

1. Completion of infrastructure (local streets and sidewalks, parking, parks and children's playgrounds) for the Al Hadba Khdra and Airport Road east sites;

2. Coordinate the entrances and the existence of housing sites, especially for the Al Hadba Khdra and Airport Road east sites to ensure the safety of and protect residents from the rapid traffic of the highway;

3. Implementation of a rainwater drainage network to collect rainwater as a benefit for irrigation of gardens in Al Hadba Khdra and Airport Road east to achieve part of the principles of housing sustainability;

4. Maintenance of an external sewage network for apartments;

5. Granting loans to residents of the housing units for the purpose of maintaining their housing units according to their needs and requirements such that they do not have a negative effect on the basics of construction and design of the apartments;

6. Maintenance and development of an external lighting network, including the development of lighting poles (use of solar panel technology to operate street and park lighting poles).

7. Activating and developing Law No. (19/1989) regulating joint ownership of buildings. 
8. Installation of insulating materials into facades of housing apartments to ensure thermal comfort inside the housing units, to prevent the entry of sunlight into residential units, as well as to conserve natural energy sources and reduce the use of air conditioning units.

\section{Aitport road site recommendations}

In addition to the general recommendations for the case study sites, the layout plan of the Airport site needs to be redesigned to protect the residents from Airport Road, which forms a boundary on the west side of the site location. Figure 36 shows a proposed layout plan for the site including ideas to develop the environment with a children's playground, parking and controls of traffic movements as well as linking the site to the surrounding neighborhoods with pedestrian paths (pedestrian bridges or pedestrian tunnels) to facilitate access to some of the services available in these neighborhoods, especially with the airport highway side.

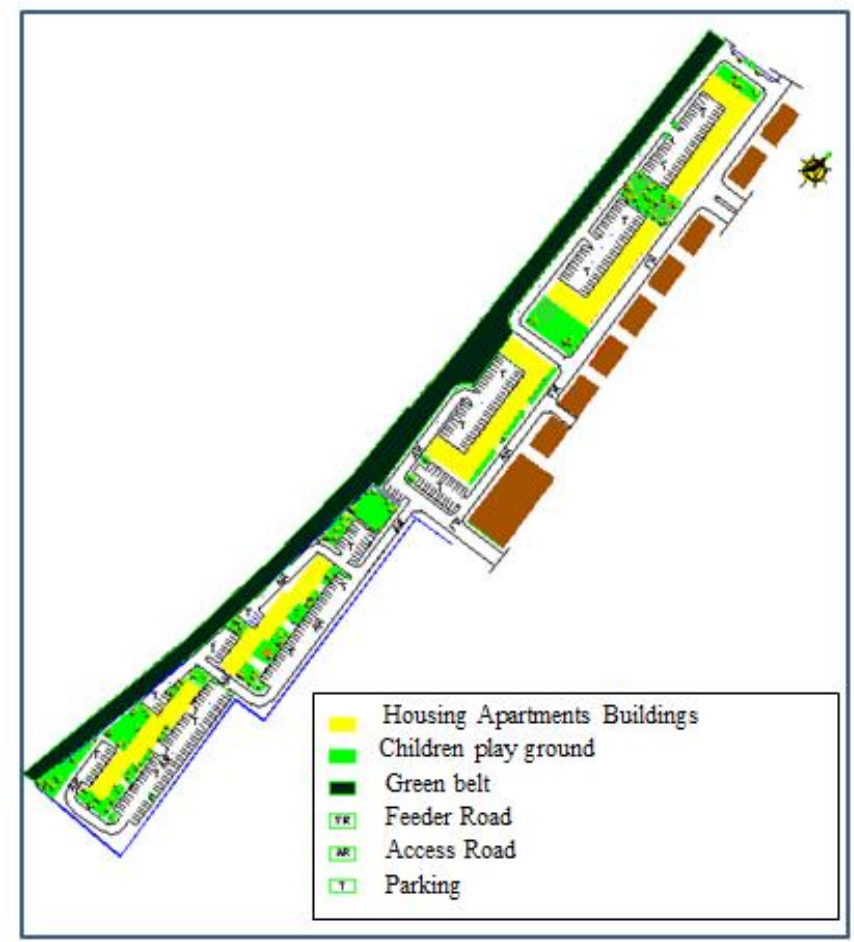

Figure 36. Airport proposal layout plan

(Source: Housing and Infrastructure Board, CMHP 2870 - 2018,

Redesigned by O. A. Alameen)

\section{Hadba-Elkadra site recommendation}

According to the evaluation of the SWOT analysis and the general recommendations, the main recommendations for the Hadba Elkadra site can be summarized as follows:

- Completion of construction of the external works (infrastructure) of the site, local streets, pedestrian paths, children's playgrounds and parking. Figure 37 illustrates the Hadba Elkadra site layout plan. 
- Provision of public services on site such as parks, children's playgrounds and pedestrian paths; for this dimension, approximately $64 \%$ of respondents were not satisfied.

- Encouraging interest in the environment and management of residential buildings.

- Creating and implementing ramps at the entrances of buildings for users with disabilities and for elderly people.

- Linking the site to the surrounding neighborhoods with pedestrian paths (pedestrian bridges or pedestrian tunnels) to facilitate access to some of the services available in these neighborhoods.

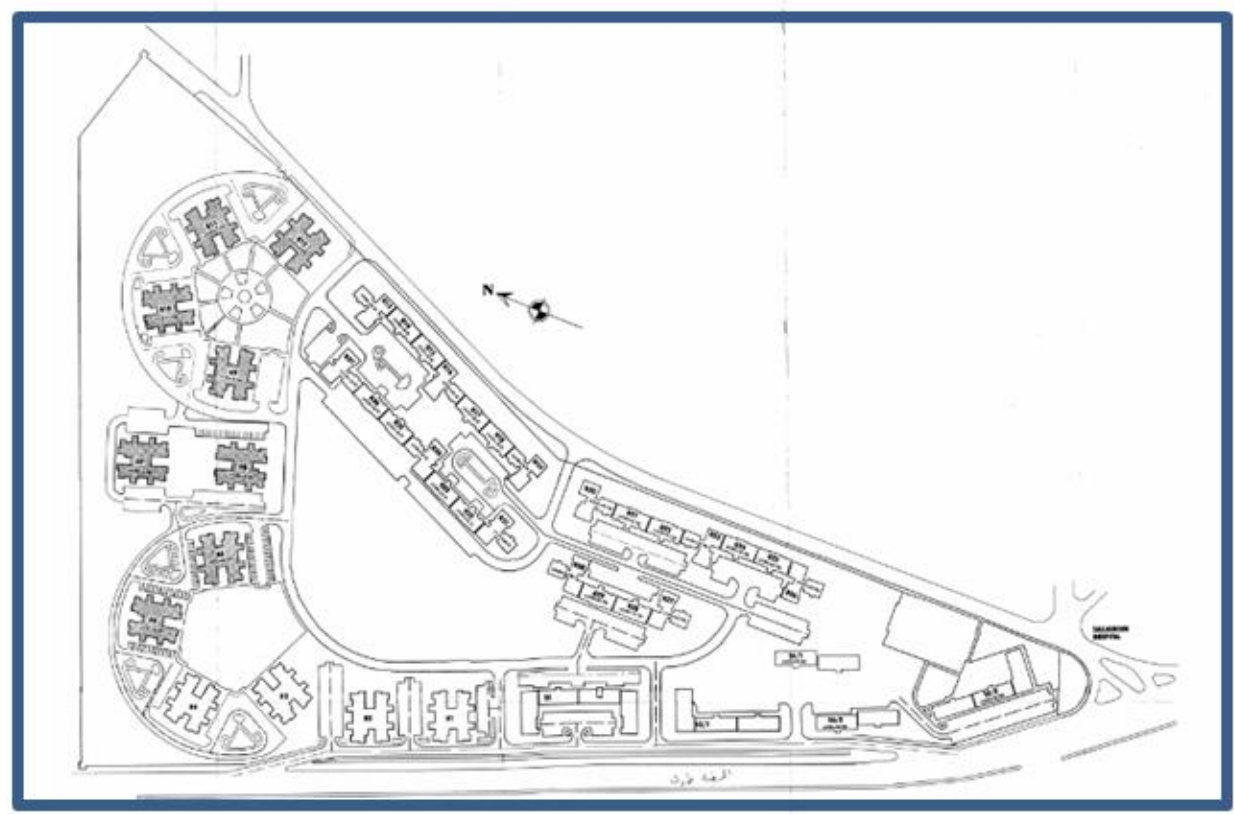

Figure 37. Hadba - Elkadra site layout plan

(Source: Housing and Infrastructure Board, CMHP 2870 - 2018)

\section{Ghot Ash Ahaal site recommendations}

With the exception of the main feeder streets, the construction on the site is mostly complete; therefore, in addition to the general recommendations, the main recommendations for Ghot Ash Ahaal site may be summarized as:

- Completion of the construction of the external works for the feeder streets around the site; Figure 38 shows the layout plan of the site.

- Provision of parking, children's playgrounds and commercial services.

- Creation and implementation of ramps at the entrances of buildings for users with disabilities and for the elderly. 
- Linking the site to the surrounding neighborhoods with pedestrian paths (pedestrian bridges or pedestrian tunnels) to facilitate access to some of the services available in these neighborhoods.

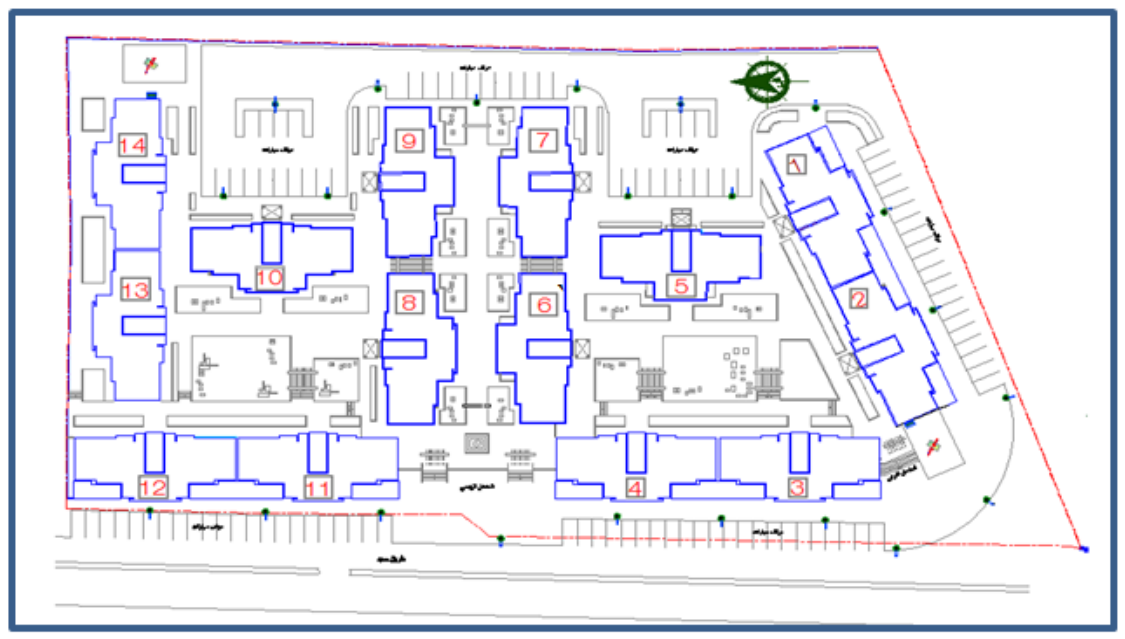

Figure 38. Ghot Ash Ahaal site layout plan

(Source: Administrative Centers Development Authority, 2018)

\section{Souq Atolata (north) site recommendation}

The site is located in the center of Tripoli and completely constructed with parking and streets in good condition. The site needs to maintain the gardens and provide adequate playground equipment for children, in addition to the general recommendations. Figure 39 illustrate the layout plan of the project.

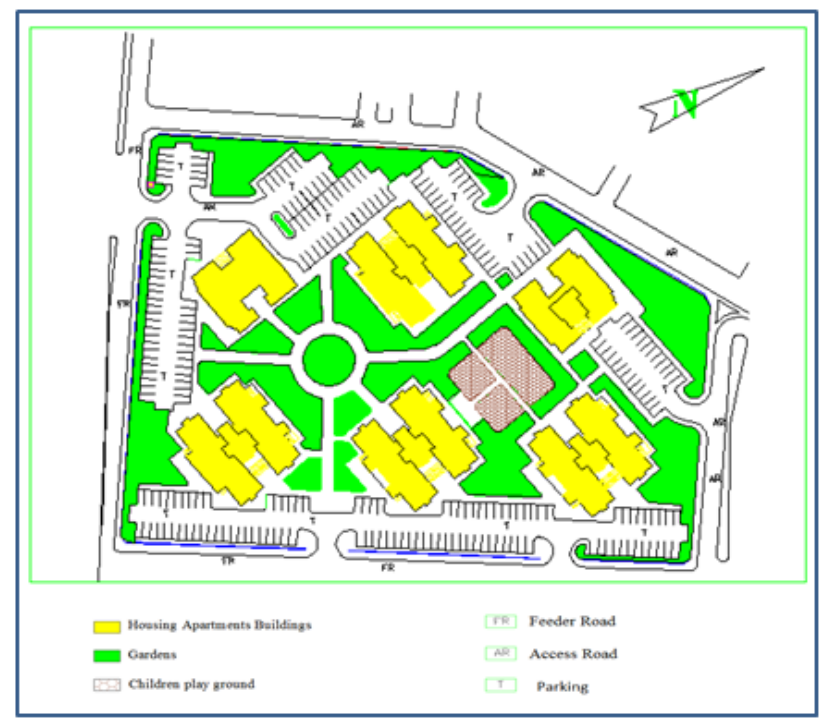

Figure 39. Souq Atolata (North) Site layout plan

(Source: Housing and Infrastructure Board, CMHP 2870 - 2018, Redesigned by O. A. Alameen) 


\section{Further Studies}

These results indicate that the users mostly are not satisfied with the social, environmental and architectural design of the housing projects in Tripoli. Due to the lack of guidelines for principles of sustainable housing, further studies are required in the future to establish guidelines and guiding principles for designers of estates in order to fulfill the desires of users according to the results of this paper.

\section{REFERENCES}

Aisha A. Almansuri, Steve Curwell, David Dowdle, (2010), Designing a Dwelling Unit in Tripoli Libya by Using Sustainable Architectural Principles, University of Salford, UK.

Almansuri A. Dowdle D. Curwell S. (2008) The Effects of Passive Design and Renewable Energy in Producing Low Energy Efficiency Architecture and Special Identity - (Case Study Libyan Desert Zone - Ghadames). In: Cásenský M. Ahmed V. Eaton D. Sutrisna M. ed. BuHu 8th International Postgraduate Research Conference. Prague, Czech Republic: University of Salford.

Awotona, A. (1990). Housing in Libya: 1950-1980, HABITATINTL. Vol 14, No.1

Betchart Expeditions. Retrieved from http://www.betchartexpeditions.com. Accessed on 11th Dec 2018.

Climate, Average Weather of Libya. Retrieved from http://www.libya.climatemps.com. Accessed on Jun 2018.

Doxiadis Associates. (1964), b. Housing in Libya: Vol. 2- Problems, Policies, programs, a report prepared for the Government of Libya.

ECOU and AKT-IAURIF. (2009). Tripoli Urban and Architectural Charter. Tripoli, ECOU.

Edwards B. and David Turrent. (2005). Sustainable Housing Principles \& Practice, this edition published in the Taylor \& Francis e-Library, UK.

Elaiab, Fatima M. (2014). Thermal comfort investigation of multi-story residential buildings in the Mediterranean climate with reference to Darnah, Libya. $\mathrm{PhD}$ thesis, University of Nottingham.

Housing and Infrastructure Board (HIB), Program Management Department (PMD), (2009), Guidance Document "Design Criteria for Housing Projects”, AECOM.

Inita Henilane,(2016), Housing Concept and Analysis of Housing Classification, Baltic Journal of Real Estate Economics and Construction Management, ISSN: 2255-9671 (online)

Kshedan, H. S (1984). The Spatial Structure of Tripoli City As Example of A Third World Socialist City. Oklahoma City, USA: University of Oklahoma. 
Lawrence, R. (2002). What makes a house a home? Reconsidered. Paper presented at the 17th Conference of the International Association for People-Environment.

Mumtaz, K. (1995). Housing Finance. Manual for Developing Countries ABC associates, USA Proposal by PICIC.

NCB (National Consulting Bureau). (2009). Analysis of the existing satiation of the Master plan of Greater Tripoli. Authority of Urban Planning Libya.

NCID (National Corporation for Information and Documentation) .(1995).Survey of Building, Housing Establishment in Libya. Government Printers. Tripoli, NCB.

Omar, A., (2003). An Evaluation of Low-Income Housing Projects in Developing Countries Case Study: Tripoli-Libya, University of Salford, Salford M5 4WT.

Oyebanji, A.O. et al (2017). Critical Success Factors (CSFs) for achieving sustainable social housing (SSH). International Journal of Sustainable Built Environment, http://dx.doi.org/10.1016/j.ijsbe.2017.03.006

Paul G. Tuohy, (2006). Sustainable Housing, thesis constructs a review of current thinking on sustainable housing, UK.

Paul Hendler and Lisa Thompson-Smeddle, (2000), Sustainable Housing, Department of Housing, National Housing Code, Pretoria: Department of Housing.

Remenyi, D., Williams, B., Money, A., and Swartz, E. (1998) Doing research in business and management. London: Sage.

Roaf, S., Crichton, D., Nicol, F., (2005). Adapting Buildings and Cities for Climate

Change. Architectural Press, Elsevier.

Jeffrey R. Edwards \& Others, (2000), On the Nature and Direction of Relationships Between Constructs and Measures, Copyright 2000 by the American Psychological Association.

Yin, R. K. (1994). Case study research: design and methods (3th Ed.). Thousand Oaks, CA: Sage.

Sekaran, U. (2003), Research Methods for Business: a skill-building approach, 2ed edition, New York, Wiley.

UN-Habitat. (2012). Sustainable Housing for Sustainable Cities, A Policy Framework for Development countries, first published in Nairobi in 2012.

World Bank. (1960). the Economic Development of Libya. Baltimore, the International Bank for Reconstruction and Development. World Socialist City, unpublished PHD thesis, University of Oklahoma, Graduate College, USA. 


\section{BIOGRAPHY OF AUTHORS}

\section{Omar Ali Alameen}

The author completed bachelor of Urban Planning Engineering, Department of Urban Planning, Faculty of Engineering, University of Gar - Younis 1985, Benghazi - Libya. He completed Master of Architecture Engineering and Urban Planning, Department of Architecture and Urban Planning, Faculty of Engineering Al- Mergib University 2006, Al-Khums Libya. From 2008 to end 2014, he was a full-time faculty member with the degree of lecturer in the Department of Architecture and Urban Planning - Faculty of Engineering at Al-Mergib University Libya. He worked as a manager of Urban Planning Authority Al- Mergib branch, and private consultant designer for Architecture and urban planning projects (1986 - 2006). He is a $\mathrm{PhD}$ student from 2015, Çankaya University, Faculty of Architecture, Graduate School of Natural and Applied Sciences Balgat / Ankara / TURKEY.

Mobile: + 905462961434 e-mail: omar3228570@gmail.com

\section{Prof. Dr. Gülser Çelebi}

Graduated from ADMMA Department of Architecture in 1976 and started to work as a research assistant. She completed her master's degree in 1982 and received the title of MSc in Educational Sciences. Having completed her PhD study in 1994, Çelebi achieved the degree of Assist. Prof. Dr. in Gazi University Faculty of Architecture. She became an Associate Professor in Building Sciences and Construction Technologies in 1999, and became a Professor in 2005. Throughout her academic life, she taught undergraduate and graduate courses, and directed to $\mathrm{PhD}$ and $\mathrm{MSc}$ thesis. Her research and studies are in the fields of sustainable architecture, environmental effects of building materials, innovative building materials and technologies, smart buildings. Çelebi, has written numerous national and international articles, published scientific meeting papers, professional journal publications, books and chapters in the books. She has also managed professional and scientific research projects, and worked as a referee in various international journals. In addition to her intensive and busy academic life, she also has administrative experiences at different universities such as 'dean' and 'vice-rector' positions. She still works as a faculty member at Çankaya University Faculty of Architecture.

Mobile: + 905377918141 e-mail: gulsercelebi@gmail.com

\section{Prof. Dr. Mehmet Tunçer}

Graduated from Middle East Technical University, Ankara, City and Regional Planning Department in 1980. Completed his MsC in METU Restoration Dep.; then continued Ankara University, Public Administration and Political Sciences Dep.(Urban Environmental Sciences) completed PhD Thesis in 1995, he received the title "Associate Professor of Urban Conservation" and become Professor in 2009. He worked as a project manager and consultant in the many fields of urban and regional planning, especially in conservation and renewal plans and projects, urban design and landscape projects since 40 years. He has 9 books published, 18 joint books on urbanization, environmental protection policies, around more than 70 papers presented and 
published in international and national scientific meetings, and numerous articles. He is a full-time faculty member at Cankaya University, Faculty of Architecture, Department of City and Regional Planning.

Mobile: + 905334410104 e-mail:mtuncer@cankaya.edu.tr 